\title{
非水溶媒環境下における特異なイオン会合現象とその解明
}

\author{
北條 正 司 $^{1}$
}

\section{Elucidation of specific ion association in non-aqueous solution environments}

\author{
Masashi $\mathrm{HoJO}^{1}$ \\ ${ }^{1}$ Faculty of Science, Kochi University, Akebono-cho, Kochi-shi, Kochi 780-8520
}

(Received 14 April 2004, Accepted 17 June 2004)

\begin{abstract}
In aqueous solution, alkali metal and alkaline earth metal salts are regarded to be "indifferent salts" or supporting electrolytes, which should change the activity coefficients of ionic species. Although higher ion aggregates from $1: 1$ type electrolytes in low-permittivity media $\left(\varepsilon_{\mathrm{r}}<10\right)$ are widely accepted, only few chemists have recognized higher ion aggregation in higher permittivity media. However, we have clarified that the chemical interaction, such as coordination, can operate between anions and cations in non-aqueous solvents $\left(20<\varepsilon_{\mathrm{r}}<65\right)$ of low solvation ability. Acids (HA) and their conjugate base anions $\left(\mathrm{A}^{-}\right)$may react with each other to form homoconjugated species, such as $\mathrm{A}^{-}(\mathrm{HA})_{2}$, in acetonitrile or benzonitrile, protophobic aprotic solvents with low hydrogen-bonding donor and acceptor abilities. After observing the direct reaction of some anions $\left(\right.$ e.g. $\left.\mathrm{Cl}^{-}\right)$and cations $\left(e . g . \mathrm{Li}^{+}\right)$toward a certain species, we comprehensively interpreted the salt effects in chemical equilibria, based on distinct chemical interactions and not merely a vague term, "medium effect". A reaction manner similar to that in non-aqueous solution can take place, even in some "aqueous" solution, if the water structure of the aqueous solution is completely destroyed, because the properties of bulk water should arise from a huge network of water molecules by hydrogen bonding; otherwise, the properties of water must be reduced to just those of isolated $\mathrm{H}_{2} \mathrm{O}$ molecules, termed, "dihydrogen ether". The chemical interaction between ions has been proved in "aqueous" solution of low water-structuredness with the addition of concentrated salts and non-aqueous solvents; a minor increase of the intermediate species that would never be observed in the chemical equilibrium sense could be multiplied into a measurable change in the chemical kinetics.
\end{abstract}

Keywords : non-aqueous solvent; acetonitrile; ion association in higher permittivity medium; water structure by hydrogen bonding; property of bulk water.

\section{1 はじめに}

水溶液中では，比較的低濃度のアルカリ金属やアルカリ 土類金属塩は支持電解質又は「無関倸塩」と見なされるこ とが多い。「無関係塩」の効果は，イオン間の静電相互作 用に基づく Debye-Hückel 理論を用いて評価することがで きる.しかし, $1: 1$ 型強電解質水溶液の場合でも, 濃度 が約 $0.1 \mathrm{~mol} \mathrm{~kg}^{-1}$ 以上では, Debye-Hückel 理論に扔ける 仮定や近似が成立しなくなると同時に，クーロン力以外の

${ }^{1}$ 高知大学理学部: 780-8520 高知県高知市曙町 2-5-1
特異な相互作用を考える必要が出てくることを，玉虫は指 摘している ${ }^{1)}$. 経験的な高次項を付加することにより，比 較的高濃度の塩溶液中の平均イオン活量係数を見積もるこ とができる場合もあるが, $0.1 \mathrm{~mol} \mathrm{dm}^{-3}$ 程度を超えると， 「強電解質」でさえイオン対等を生成し, 完全解離できな くなるのであるから, 完全解離を前提にしている理論式 に, 破簁が生じるのは当然のことと言えるかもしれない.

これまでに，著者らは溶液中に扔けるイオン間の相互作 用について研究してきた。その成果として，溶媒和力にそ しい非水溶媒, 特に, 非プロトン性（水素結合供与性に忌 しい）で更に疎プロトン性（水素結合受容性がそしい）の 
溶媒中では，アルカリ金属及びアルカリ土類金属イオン等 と陰イオン $\left(\mathrm{ClO}_{4}{ }^{-}\right.$等は除く）間に，静電的相互作用だけ ではなく水素結合や錯形成などの化学的相互作用が働く場 合があることを見いだした。このように，本論文では，主 に疎プロトン性の非水溶媒中の特異な化学反応を紹介し, その原因を，イオンの活量係数の変化だけに求めるのでは なく，イオン会合反応によって説明する.

完全解離を前提にした理論からの逸脱は, 非水溶媒中や 有機溶媒混合水溶液中，濃厚な塩を含む水溶液で著しい が，そのほかに，界面が関与する分析手法，すなわち，溶 媒抽出法や液体クロマトグラフ法における平衡反応や反応 速度においても認められる。これらの系中で，反応の特異 性が発現しやすいのはなぜなのか，考察を進めていきた い.

\section{2 非水溶媒中の残余水の影響評価}

アセトニトリル等の非水溶媒中には，脱水後も必然的に 少量の水（数 $\mathrm{mM}$ 程度）が含まれている。このため, 通 常取り扱う非水溶媒の性質は,「完全脱水」溶媒のそれと は大きく掛け離れているのではないかという疑念がいつも つきまとっている. Coetzee と Kolthoff ${ }^{2)}$ は，70\% 過塩素 酸の水分と当量の無水酢酸を加えることによって，無水の 過塩素酸一酢酸溶液をつくり，それをアセトニトリルで希 釈して, 無水の過塩素酸-アセトニトリル溶液を調製し, 塩基の滴定に用いた。しかし，この方法では，混在する酢 酸ため，対象となる反応を妨害する恐れがある．池田ら ${ }^{3)}$ は，蒸留法により無水の過塩素酸を調製して， $\mathrm{CH}_{3} \mathrm{CN}$ と $\mathrm{HClO}_{4}$ 間の酸 - 塩基相互作用を研究した。非水溶媒中の水 の含量は, カール・フィッシャー法又は分離カラム Porapak Qを用いるガスクロマトグラフ法 ${ }^{4}$ によって定量 できる.

ところで, 非水溶媒中に存在する微量の水 (残余水) は, 溶存する化学種の化学平衡・反応速度に対して, 特殊な場 合を除き，大きな影響を及ぼさないと考えられるが，その 根拠を次に示したい.バルク水は水素結合のネットワーク により高度に構造化している。一般に知られている水の特 性は，バルク水（集団）に由来するものである. バルク水 はかなり「強い」酸として，また，かなり「強い」塩基と しても作用できる。しかしながら，「孤立した」水分子は 他の水分子との相互作用がない，又は他の水分子からの補 助がないために，バルク水とはかなり異なる性質を示すと

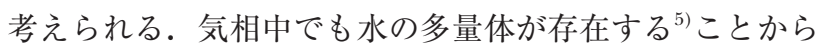
考察すると，水の完全な孤立分子状態は，高温で低密度の 水蒸気によってのみ達成されるかもしれないと思われる.

「孤立した」水 $\left(\mathrm{H}_{2} \mathrm{O}\right)$ の酸性度又は塩基性度とジエチ ルエーテル $\left(\mathrm{Et}_{2} \mathrm{O}\right)$ やメタノール $(\mathrm{MeOH})$ のそれとの 間には，大きな相違を見いだしにくい．例えば，ジクロロ

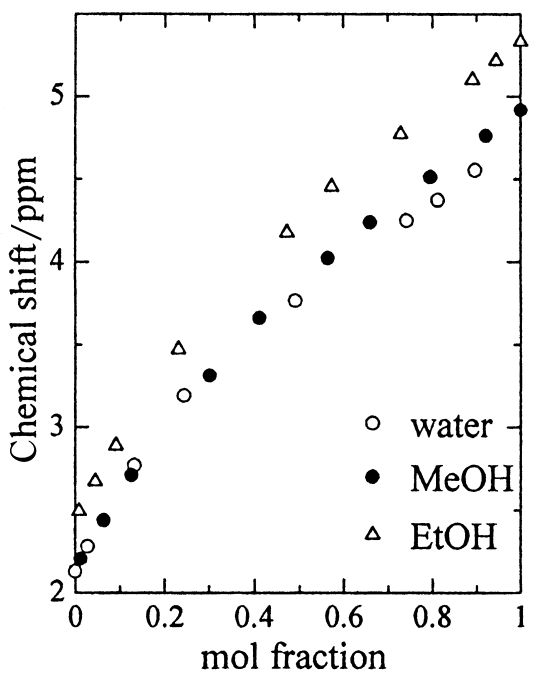

Fig. 1 The changes of $\mathrm{OH}$-proton chemical shift values for water, methanol, and ethanol in $\mathrm{CD}_{3} \mathrm{CN}$

エタン中に分散した低濃度の水（1 mM 程度）の化学反応 熱に基づく水のドナー数故は 18.0 とされており，この值は $\mathrm{Et}_{2} \mathrm{O}$ 又は $\mathrm{MeOH}$ のドナー数とほとんど同じである。 Gutmann $^{6)}$ は，バルクの溶媒としては異常なエントロピ 一効果をもつ水さえも, ジクロロエタン中に希薄溶液とし て存在するときには，（構造性がない，又は構造性にそし い）他の溶媒と直線関係によく乗ることは注目すべきこと であると述べている，水素結合（相互作用）によらない本 来の単独水分子の酸性度は，バルク水から類推されるもの より，極端に小さい。水の $\mathrm{O}-\mathrm{H}$ 結合のエンタルピーは $463 \mathrm{~kJ}^{7)}$ であり，メタンの C-H 結合エンタルピー $413 \mathrm{~kJ}^{7)}$ よりも大きいほどであり，全く簡単には解離できないので ある。

Fig. 1 にアセトニトリル（MeCN） 中の水の含有量変化 による $\mathrm{H}_{2} \mathrm{O}$ プロトン核磁気共鳴（NMR）ケミカルシフト 值（TMS 基準）の変化を示している（未発表データ）。脱 水したアセトニトリル中に残存する微少量の水のケミカル シフト值は約 2.1 であるが，水含量の増加に伴い，ケミカ ルシフト值がバルク水のそれに近づいている．水素結合に よる構造性を有するメタノール，エタノール及びその他の アルコール類についても水の挙動と同様の変化を示した. Silverstein $ら^{8)}$ は,「塊りの水」と「孤立した水」の違いを 次のように記述している。懸濁した水滴又は試料管の壁に フィルム状で存在するような“塊りになった” 水は $\mathrm{CDCl}_{3}$ 中で $\delta$ 約 4.7 にピークを与える。溶解した（単量体）の水 は $\mathrm{CDCl}_{3}$ 中において $\delta$ 約 1.5 で吸収し，希薄溶液ではス ペクトルの重要な部分を著しく妨害する．アセトンやジメ チルスルホキシド（DMSO）中においても，残余水又は少 量の水のケミカルシフト值はやはり小さく，逆に，多量に 混合された水はバルク水に近くなっている ${ }^{9)}$. 


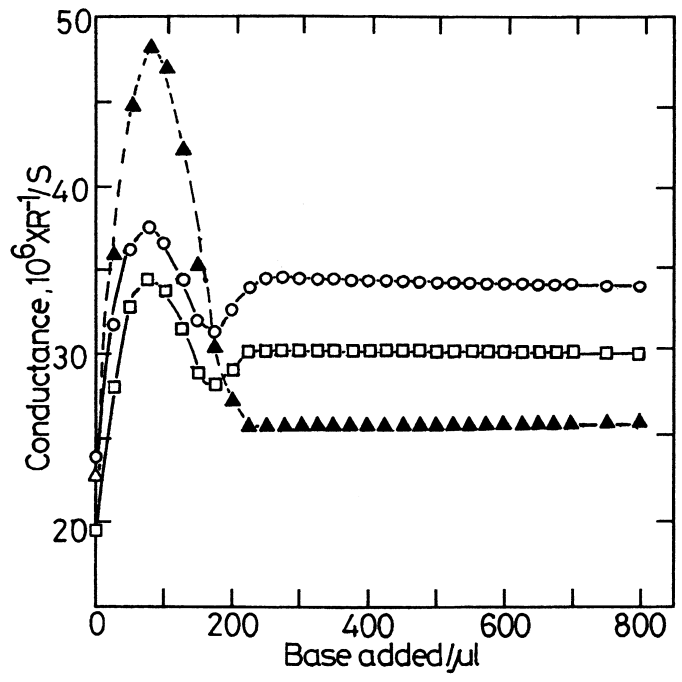

Fig. 2 Conductometric titration curves of $0.0050 \mathrm{M}$ sulfonic acids $(25 \mathrm{ml})$ with $0.50 \mathrm{M}$ triethylamine in benzonitrile at $25^{\circ} \mathrm{C}$

( $\Delta$ ) methansulfonic; $(\square)$ p-toluenesulfonic ; $\bigcirc$ ) benzenesulfonic acids

以上のように，非水溶媒中に分散して存在する微量の残 余水は, バルク水とは異なり, 大きな集団を形成すること ができないため，その酸性度及び塩基性度は共に極めて小 さくなる，言い換えると，非水溶媒中の水は，その濃度が 十分に低いときには，同濃度のジエチルエーテルと同程度 の効果しか及ぼさないと, 著者らは考えている. しかしな がら, 強力なルイス酸 $\left(\mathrm{Al}^{3+}, \mathrm{In}^{3+}\right.$ 等) が存在するときに は，「孤立した」水分子との直接的な反応が十分あり得る. こうしたことから，純非水溶媒を扱う研究においては，溶 媒の脱水, 使用するガラス容器の乾燥, 試薬の付着水又は 結晶水の除去及び大気の湿度に至るまでに細心の注意が必 要である. 非水溶媒を扱う研究室では, 容量ガラス器具で さえ, $120^{\circ} \mathrm{C}$ の乾燥機中で, ガラス表面の水を完全に取り 除いた後に使用することが，日常的に行われている.

3 酸と塩基の特異な反応：ホモ共役及びへテロ共 役反応

水，アルコールなどの両性溶媒中では，溶媒と溶質間の 水素結合力が強いため, 溶質間の水素結合相互作用は働き にくい.しかし, 非プロトン性溶媒中では, 弱酸（HA） から生じる共役アニオン $\left(\mathrm{A}^{-}\right)$は, 非解離の酸分子と, 水素結合により相互作用し, 次式に示すようなアニオン性 のホモ共役又はへテロ共役反応を引き起こすことが可能で あり，酸塩基反応はかなり複雑になる。

$\mathrm{A}^{-}+\mathrm{HA} \Longleftrightarrow \mathrm{AHA}^{-}, \mathrm{K}\left(\mathrm{AHA}^{-}\right):$アニオン性ホモ共役

$\mathrm{A}^{-}+\mathrm{HA}^{\prime} \leftrightarrows \mathrm{AHA}^{{ }^{-}}, \mathrm{K}\left(\mathrm{AHA}^{\prime^{-}}\right):$アニオン性へテロ共

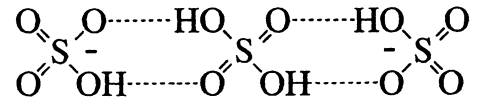

Scheme 1 The proposed homoconjugated species, $\left(\mathrm{HSO}_{4}{ }^{-}\right)_{2} \cdot \mathrm{H}_{2} \mathrm{SO}_{4}$

役（Aと A’が異なるとき）

一方，カチオン性のホモ共役及びへテロ共役反応は，弱 塩基（B）とその共役酸 $\left(\mathrm{BH}^{+}\right)$間の相互作用によって生 成する。

$\mathrm{BH}^{+}+\mathrm{B} \leftrightharpoons \mathrm{BHB}^{+}, \mathrm{K}\left(\mathrm{BHB}^{+}\right)$: カチオン性ホモ共役 $\mathrm{BH}^{+}+\mathrm{B}^{\prime} \leftrightarrows \mathrm{BHB}^{{ }^{+}}, \mathrm{K}\left(\mathrm{BHB}^{{ }^{+}}\right)$: カチオン性へテロ共

役（Bと $\mathrm{B}^{\prime}$ が異なるとき）

著者らは，ドナー数（DN）及びアクセプター数（AN） が共に小さい（それぞれ 11.9 及び 15.5） ベンゾニトリル 中（比誘電率 $\varepsilon_{\mathrm{r}}=25.2 ）$ では, メタンスルホン酸や $p$-卜 ルエンスルホン酸などのスルホン酸類 (HA) さえも弱酸 として作用し，1:2 型ホモ共役種 $\mathrm{A}^{-}(\mathrm{HA})_{2}$ を生成するこ とを, 導電率滴定法（Fig. 2）により明らかにした。とこ ろで, Kolthoff と Chantooni ${ }^{10)}$ は MeGN 中において, ブ チルアミンにより $\mathrm{H}_{2} \mathrm{SO}_{4}$ を導電率滴定し, $2 / 3$ 当量点に おいて，明瞭な導電率の極大を観測した。この実験結果 を, $1: 1$ 型ホモ共役種の生成 $\left(\mathrm{HSO}_{4}{ }^{-} \cdot \mathrm{H}_{2} \mathrm{SO}_{4}\right)$ に起因す ると結論付けている. しかしながら，2/3 当量点において 極大が生じるのなら，1:1 型種ではなく，二つの共役塩 基イオンと一つの酸分子による $2: 1$ 型ホモ共役種の生成 (Scheme 1) に基づくとすべきであると著者らは論じ た ${ }^{11)}$.

ドナー数が大きな $N, N$-ジメチルホルムアミド（DMF） 中 $(\mathrm{DN}=26.6)$ においてさえ, リン酸類はホモ共役など の会合種を生成する ${ }^{12)}$ 。このとき $1: 1$ 型ホモ共役種の安 定性は，ホモ共役にかかわる (リン酸類の) $\mathrm{OH}$ 基の個数 に依存すること, すなわち, $(\mathrm{PhO}){ }_{2} \mathrm{PO}(\mathrm{OH})$ よりも $\mathrm{PhOPO}(\mathrm{OH})_{2}$ や $\mathrm{PO}(\mathrm{OH})_{3}$ のほうが安定なホモ共役種を 形成できることを実証した (Scheme 2 参照).

4 アルカリ金属イオンが関与する錯形成反応

$4 \cdot 1$ アザクラウンエーテルとアルカリ金属イオン間の 相互作用

アルカリ金属イオンの錯形成能力は, 言うまでもなく, 遷移金属イオンのそれよりもはるかに小さく, 希薄な水溶 液ではほとんど認められないとされる。しかし，水溶液中 では，アルカリ金属イオンは，既に水分子による錯形成， すなわち，水和を受けていることを念頭に置かなくてはな 


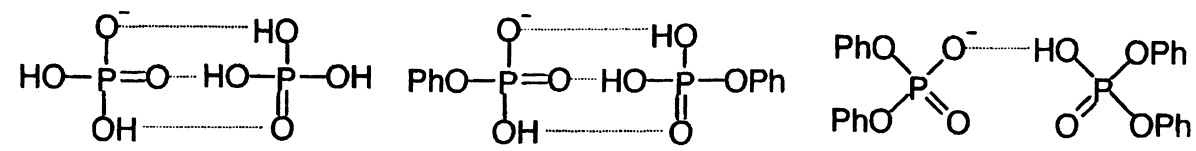

Scheme 2 Homoconjugation with single and multiple hands between $\mathrm{HA}$ and $\mathrm{A}^{-}$in DMF

らない.クラウンエーテルをはじめとする大環状化合物と アルカリ金属イオンとの相互作用「錯形成」は，様々の手 法により広範に研究されている ${ }^{13)}$.

アザクラウンエーテル類は，MeCN 中でポーラログラ フ法の水銀溶出波を与えるが, アルカリ金属等のルイス酸 の共存によって，陽極波の半波電位 $E_{1 / 2}$ が正電位側にシ フトする。この正側への電位シフトを利用して, 各種のア ザクラウンエーテル類とアルカリ金属イオン等との錯生成 定数を求めた ${ }^{14) \sim 16)}$. また, 同様にして鎖状のポリアミン 類とアルカリ金属イオンとの相互作用の大きさを見積もっ た ${ }^{17)}$.

\section{$4 \cdot 2$ 配位結合と「逆配位」("reverse-coordination")}

$\mathrm{MeCN}$ 中で $\mathrm{Li}^{+}, \mathrm{Na}^{+}$及び $\mathrm{K}^{+}$の過塩素酸塩に対して, 安息香酸イオン $\left(\mathrm{PhCOO}^{-}\right)$は, 2 個配位し, 安定な錯体 を生成することを通常のポーラログラフ法により見いだし た。 大過剩の $\mathrm{PhCOO}^{-}\left(\mathrm{Et}_{4} \mathrm{~N}^{+}\right)$共存による金属イオンの 半波電位の負側へのシフトから, 全生成定数 $\left(K_{\mathrm{f}} / \mathrm{M}^{-2}\right)$ をそれぞれ $10^{16.7}, 10^{8.4}$ 及び $10^{4.2}$ と見積もった ${ }^{18)}$ 。また， $\mathrm{LiClO}_{4}$ に $\mathrm{Cl}^{-}\left(\mathrm{Et}_{4} \mathrm{NCl}\right)$ を多量に添加すると, $\mathrm{Li}^{+}$の還元 波の半波電位は負側にシフトするが，この負側へのシフト を解析し, $\mathrm{Li}^{+}\left(\mathrm{Cl}^{-}\right)_{n}(n=1 \sim 4)$ の生成定数を求めた ${ }^{19)}$.

逆に, $\mathrm{CH}_{3} \mathrm{COO}^{-}, \mathrm{PhCOO}^{-}$(共に $\mathrm{Et}_{4} \mathrm{~N}^{+}$塩) に対し, 当量程度の $\mathrm{Li}^{+}$又は $\mathrm{Na}^{+}$を共存させると $\mathrm{RCOO}^{-} \mathrm{M}^{+}$の沈 殿が生じるが，そこに大過剩の金属イオンを加えると，沈 殿は再溶解することから，「逆配位」種 $\mathrm{RCOO}^{-}\left(\mathrm{M}^{+}\right)_{2}$ が 生成することを提案した ${ }^{18)}$.ここで，「逆配位」とは単電 荷の陰イオン 1 個に対して複数の金属イオンが結合する ことを意味し，逆供与（back donation）とは全く異なる 概念である (引用文献 ${ }^{20}$ 参照)。また, $\mathrm{RCOO}^{-}$に対し, 多 量の共役酸（HA）を添加すると，1個の陰イオンに対し て 2 個の酸分子が結合した，ホモ共役種 $\left[\mathrm{RCOO}^{-}(\mathrm{HA})_{2}\right]$ が生成することを確認した。 MeCN 中の「逆配位」種の 生成の可能性については, 既に $\beta$-ジケトンであるアセチ ルアセトナトイオン及び酢酸イオンについて，それぞれ Murray $^{21)}$ 及び板橋 ${ }^{22)}$ が示唆していた。

紫外・可視吸収スペクトル法によっても，カルボン酸イ オンについての「逆配位」種の生成が明らかになった ${ }^{23)}$. Fig. 3 には, $\mathrm{LiClO}_{4}$ 又は $\mathrm{NaClO}_{4}$ の濃度の増加に伴う $\mathrm{C}_{6} \mathrm{H}_{5} \mathrm{COO}^{-}$の約 $225 \mathrm{~nm}$ のピークの吸光度の変化を示して いる. 当量付近の金属イオンの共存により白沈が生じ，吸

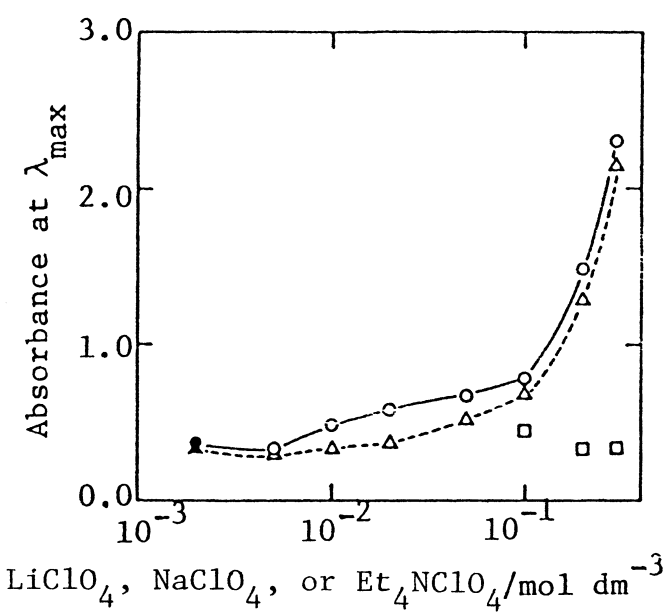

Fig. 3 The absorbance change of the benzoate ion $\left(2.0 \times 10^{-3} \mathrm{M} \mathrm{C}_{6} \mathrm{H}_{5} \mathrm{COOEt}_{4} \mathrm{~N}\right)$ by the addition of an excess of $\mathrm{LiClO}_{4}(\bigcirc), \mathrm{NaClO}_{4}(\triangle)$, and $\mathrm{Et}_{4} \mathrm{NClO}_{4}(\square$, containing $2.0 \times 10^{-3} \mathrm{LiClO}_{4}$ )

Solid marks show the equivalent amount.

光度は低くなっているが, 100 倍量の金属イオンの共存に より沈殿は再溶解し, 吸光度は著しく増大している. しか し， $\mathrm{LiClO}_{4}$ を加えることにより生じた沈殿に対し，非金 属塩の $\mathrm{Et}_{4} \mathrm{NClO}_{4}$ を大過㮃添加しても塩が再溶解すること はなかった，上記のような溶解度の変化はさておき，スぺ クトルの変化によっても「逆配位」種の生成が観測された (Fig. $4 \mathrm{a}$ 及び $4 \mathrm{~b}$ 参照).2,4-ジニトロ安息香酸イオン $\left(\mathrm{A}^{-}\right)$ に対して当量までの $\mathrm{LiClO}_{4}$ を添加すると, 沈殿が生じる ことなく $300 \mathrm{~nm}$ 付近の吸光度が減少し，代わりに 250 $\mathrm{nm}$ 付近の吸光度が増大した。このとき出現した $297 \mathrm{~nm}$ の等吸収点は $\mathrm{A}^{-}$と $\mathrm{Li}^{+} \mathrm{A}^{-}$の共存を示している。当量を越 える金属イオンの添加により，等吸収点は $291 \mathrm{~nm}$ に移行 したが，この等吸収点は $\mathrm{Li}^{+} \mathrm{A}^{-}$と $\left(\mathrm{Li}^{+}\right)_{2} \mathrm{~A}^{-}$の共存を示唆 していると思われる。ベンゾニトリル中において，ピクリ ン酸イオンに対し過剩の $\mathrm{Li}^{+}$を添加すると, 同様の等吸収 点の移動が起こり, $\mathrm{Li}^{+}$とピクリン酸イオン間のイオン対 及びイオン対を超える「逆配位」種の生成が確認され た . $^{24)}$.

ベンゼンスルホン酸イオンに対して，過剩の $\mathrm{Li}^{+}$が共存 する場合には，複数個の $\mathrm{Li}^{+}$が陰イオンに対して結合でき るため, いったん減少した吸光度が増加したが, $\mathrm{Na}^{+}$濃度 を増加させたときには， $\mathrm{C}_{6} \mathrm{H}_{5} \mathrm{SO}_{3} \mathrm{Na}$ 沈殿の量が増えるた けであった (Fig. 5 参照 $)^{20)}$ ・リン酸系について述べてお 

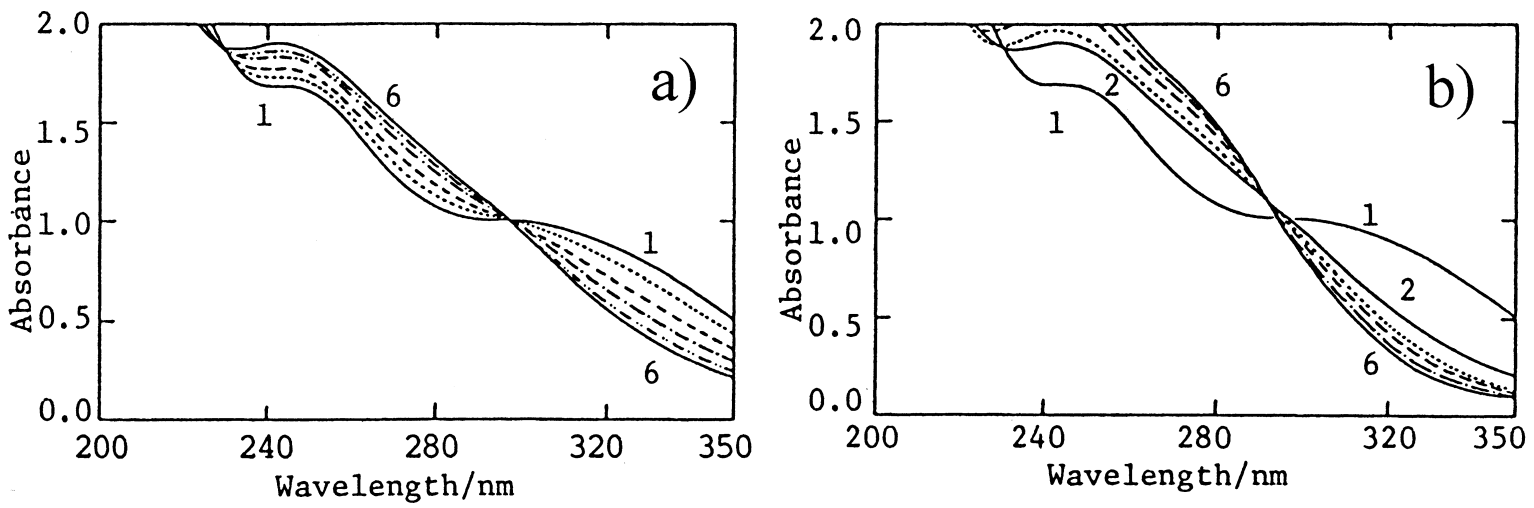

Fig. 4(a) UV spectral changes with the molar ratio (up to $1: 1$ ) of $\mathrm{LiClO}_{4}$ to 2,4-dinitrobenzoate ion $(2.0 \times$ $\left.10^{-4} \mathrm{M}\right)$ in MeCN : (- 1$) 0$; (-.---) $0.2 ;(---) 0.4 ;(-\cdot-\cdot-) 0.6 ;(-\cdot-) 0.8 ;(-6) 1.0$

Fig. 4(b) UV spectral changes of 2,4-dinitorobenzoate $\left(2.0 \times 10^{-4} \mathrm{M}\right)$ by the addition of excess amounts of $\mathrm{LiClO}_{4}$ : (- 1$) 0$; (--.--2) $2.0 \times 10^{-4} ;(---) 1.0 \times 10^{-3} ;(-\cdot-\cdot) 1.0 \times 10^{-2} ;(-\cdot-) 4.0 \times 10^{-2} ;(-6) 0.1$ and $0.2 \mathrm{M} \mathrm{LiClO}_{4}$

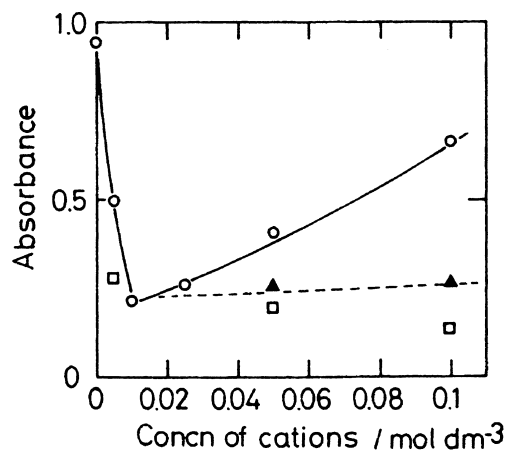

Fig. 5 Changes of absorbances of $\mathrm{Et}_{4} \mathrm{~N} \mathrm{C}_{6} \mathrm{H}_{5} \mathrm{SO}_{3}$ $\left(5.3 \times 10^{-3} \mathrm{M}\right)$ with increasing concentration of alkali metal perchlorates in MeCN: $(\bigcirc) \mathrm{LiClO}_{4} ;(\square)$ $\mathrm{NaClO}_{4} ;(\boldsymbol{\Delta}) \mathrm{Et}_{4} \mathrm{NClO}_{4}$ in addition to $0.01 \mathrm{M} \mathrm{LiClO}_{4}$

くと，アセトン中でジフェニルホスフェイトイオン $\left[(\mathrm{PhO})_{2} \mathrm{PO}_{2}^{-}\right]$と $\mathrm{Li}^{+}$間の配位及び「逆配位」種の生成定 数が求められた ${ }^{20)}$. 以上の上うに, 溶媒和力の弱い疎プロ トン性非プロトン溶媒中においては, 各種の陰イオン，カ ルボン酸イオン, スルホン酸イオン, リン酸イオン, 塩化 物イオン等は, $\mathrm{Li}^{+}$又は $\mathrm{Na}^{+}$と単に $1: 1$ 型イオン対を作 るだけではなく, $1: 2$ 及び $2: 1$ 型の会合体を生成するこ とが確実になってきた。

ここで, 過塩素酸イオンの効果について，考察してお く. 過塩素酸イオンは立体的に対称性がよく, 電荷の偏り がほとんどないので，錯形成力がほとんどないと考えてょ い. 同様に $\mathrm{BF}_{4}{ }^{-}, \mathrm{PF}_{6}{ }^{-}$など中心元素の配位数が満たされ， 立体的に対称性の良い陰イオンや $\mathrm{Et}_{4} \mathrm{~N}^{+}$などの第四級アン モニウムイオンは, クーロン相互作用はさておき, 錯形成 や水素結合などの化学的相互作用には与しないものとして 取り扱うことができる. 各種の遷移金属イオンと過塩素酸 イオン間の錯生成反応の可能性が考察されているが ${ }^{25)}$, そ

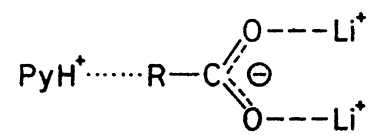

Scheme 3 The week interaction between the pyridinium ion and the acetate ion associated with lithium cations

の相互作用はあまり明確ではないといえる.

ところで, Hickey ら ${ }^{26)}$ は，ピリジン中に扔けるカルボ ン酸類のポーラログラフ的還元電位が, $\mathrm{Li}^{+}$イオンの添加 により, 過塩素酸や $p$-トルエンスルホン酸などの強酸の 還元電位と同じになる現象，すなわち，一種の「水平化効 果」を見いだした，辻ら ${ }^{27}$ は，この現象をイオン会合及び 交換反応によって説明を試みたが，著者らは「逆配位」種 $\mathrm{RCOO}^{-}\left(\mathrm{Li}^{+}\right)_{2}$ の生成に基く, フリーのピリジニウムイオ ン $\left(\mathrm{PyH}^{+}\right.$, Scheme 3 参照) の生成に基き, 水平化する 原因を定量的に説明することに成功した ${ }^{28)}$.この件に関し ては，辻から好意的なメッセージを受けたことを付記して おく.

\section{5 導電率法による高次イオン会合の研究}

\section{$5 \cdot 1$ イオン対生成と高次イオン会合}

導電率法（コンダクトメトリー）は，イオン種の輸送現 象に基づき, 溶液中の化学種の存在状態や存在量（濃度） を調べる方法である，通常の電気伝導度理論又は解析法 は，電解質が（1）完全解離するか，又は（2）会合する が，それ以外の高次の反応は起こらないことを前提にして いる。この前提条件は，希薄水溶液等については，ほほ問 題がないと思われる. しかしながら, 溶媒の誘電率が小さ くなる, 溶媒和力が弱くなる, 電解質濃度が高くなる等に よって, 溶液中で電解質からのイオンは $1: 1$ 型イオン対 


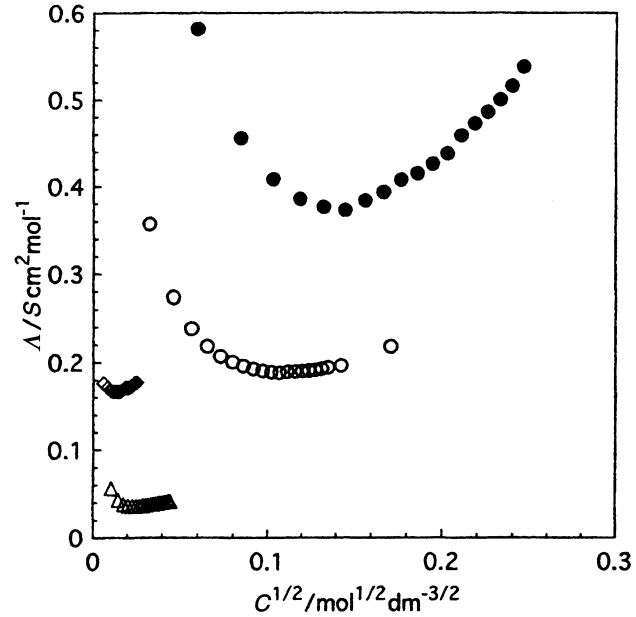

Fig. 6 Observed molar conductivities $(\Lambda)$ in THF at $25^{\circ} \mathrm{C}:(\bigcirc) \mathrm{LiClO}_{4} ;(\bigcirc)$ LiPic; $(\diamond) 2,4-\left(\mathrm{NO}_{2}\right)_{2} \mathrm{C}_{10} \mathrm{H}_{5^{-}}$ $\mathrm{OLi} ;(\triangle) \mathrm{LiNO}_{3}$

を生成するほかに，高次のイオン会合を起こすことがあり 得ると提案してきた。高次のイオン会合とイオン対生成反 応が同時に起こっている系について, 通常の電気伝導度理 論を用いて解析を試みると，仮にその理論がいかに厳密で あったとしても破綻が生じることは必至であり，解析結果 は，現実とは啡離したものになってしまうはずであり，注 意が必要となる.

\section{$5 \cdot 2$ 低誘電率溶媒中の三重イオン生成}

Fuoss $5^{29}$ は, 誘電率が低い $\left(\varepsilon_{\mathrm{r}}<23.2\right)$ 溶媒中では, イオン対とイオンとの反応（静電的な三重イオンの生成） が起こり得るとしている. 特に, 誘電率が 10 以下では, 導電率曲線上に極小が生じる場合があり，この現象が「三 重イオン生成」発見の端緒となった。極小の出現を，他の 原因に求めるなど ${ }^{3031)}$, 異論は残っているものの, 低誘電 率媒体中の高次イオン会合は, 広く受け入れられている.

テトラヒドロフラン（THF）等の低誘電率溶媒中 $\left(\varepsilon_{\mathrm{r}}<\right.$ 10) で極小が生じる塩濃度 $\left(c_{\min }\right)($ Fig. 6) と三重イオン 生成定数との間の直線性が, 初めて実証された ${ }^{32)}$. この直 線関係は，理論的には古くから予想されていたものである ${ }^{333}$ が，このように長期間，理論的予測が実証されずに残さ れていたのは, 最も基本的な塩と見なされる $\mathrm{LiCl}$ 等が低 誘電率媒体中で, 三重イオン生成反応に加えて, 大きな四 重極子生成（イオン対の二量化）反応を示すために，導電 率曲線上に極小が生じない ${ }^{32}$ こと等が原因と思われる. THF 中で四重極子が生成しにくいピクリン酸リチウム （LiPic）の分析濃度の増加に伴う単イオン，イオン対及び 三重イオンの平衡濃度の変化を Fig. 7 に示す.

$\mathrm{LiBr}$ は $\mathrm{LiCl}$ と異なり, $\mathrm{THF}$ 中で導電率曲線上に極小を 生じた $\left(C_{\min }=4.9 \times 10^{-3} \mathrm{~mol} \mathrm{dm}^{-3}\right)$. 導電率曲線上の各

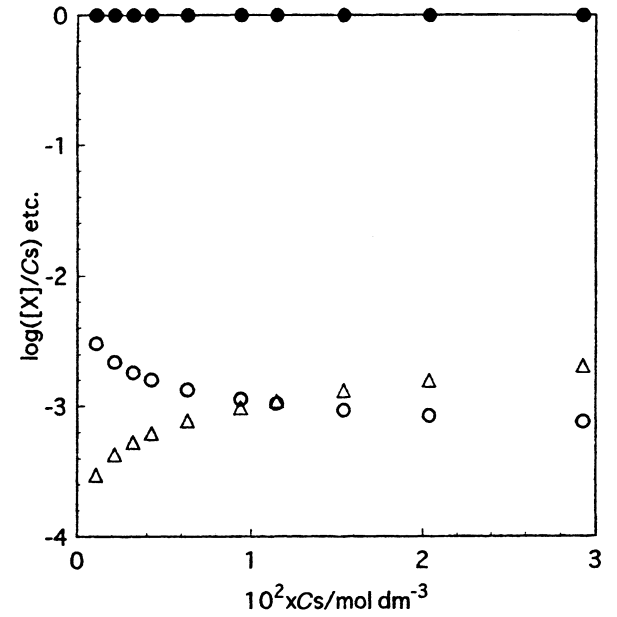

Fig. 7 Changes of equilibrium concentrations of each species with the LiPic concentration in THF: $(\bigcirc)$ simple ions; $(\bigcirc)$ the ion pair; $(\triangle)$ triple ions

塩濃度のモル導電率は, $\mathrm{Li}^{+}$と $\mathrm{Br}^{-}$間のイオン対, 対称的 な三重イオン，及び（中程度の強さの）四重極子生成反応 によって説明できた。拈もしろいことに，THF と同程度 $\left(\varepsilon_{\mathrm{r}}=7.58\right)$ の誘電率を有する 2-エチル-1-ヘキサノールを 少量添加すると，極小の生じる塩濃度が高くなった，プロ トン性溶媒の添加により, 誘電率の変化はないが, 溶媒和 力が大きくなるために，三重イオン生成が起こり難くなっ たことに起因していることを明らかにした ${ }^{34)}$.

\section{$5 \cdot 3$ 溶媒和力が弱い高誘電率媒体中における高次イオ ン会合}

溶媒和力が小さい溶媒，特に疎プロトン性非プロトン溶 媒中（水素結合の受容性及び供与性が共に極めて弱い）で は，その誘電率が高くても $\left(20<\varepsilon_{\mathrm{r}}<65\right), 1: 1$ 型電解質 からイオン対（MX）を越えて，水素結合力又は配位結合 力による三重イオン $\left(\mathrm{M}_{2} \mathrm{X}^{+}, \mathrm{MX}_{2}^{-}\right)$及び四重極子 $\left(\mathrm{M}_{2} \mathrm{X}_{2}\right)$ が生成する ${ }^{35}$. このような高次のイオン会合が起 こる場合には，Shedlovsky 法 ${ }^{36)}$ な゙ 1：1の会合だけを考 慮した解析法には破綻が生じるが，その端的な例を示して おきたい．Fig. 8 には，プロピレンカーボネート（PC） 中のトリフルオロ酢酸リチウム $\left(\mathrm{LiCF}_{3} \mathrm{COO}\right)$ の導電率曲 線を示している，イオン対生成反応により計算された導電 率 $\left(\Lambda_{\text {calc }}\right)$ は, $4 \times 10^{-4} \mathrm{M}$ 付近の低濃度におけるモル導電 率 $\left(\Lambda_{\text {obsd }}\right)$ を説明できるが，高濃度になると実測值より， 高い值になる。このように，塩濃度が高くなると，1:1 型イオン対生成により予想される導電率 $\Lambda_{\text {calc }}$ よりも実測 值 $\Lambda_{\mathrm{obsd}}$ が低くなっていくのは, 濃度の増加とともにイオ ン対の二量化が進行することによる。Wu ら ${ }^{37}$ は PC 中の トリフルオロ酢酸リチウムの導電率を測定し，解析不可能 としたが，溶液熱測定により，二量体 $\left[\left(\mathrm{Li}_{2}\left(\mathrm{CF}_{3} \mathrm{COO}\right)_{2}\right]\right.$ 


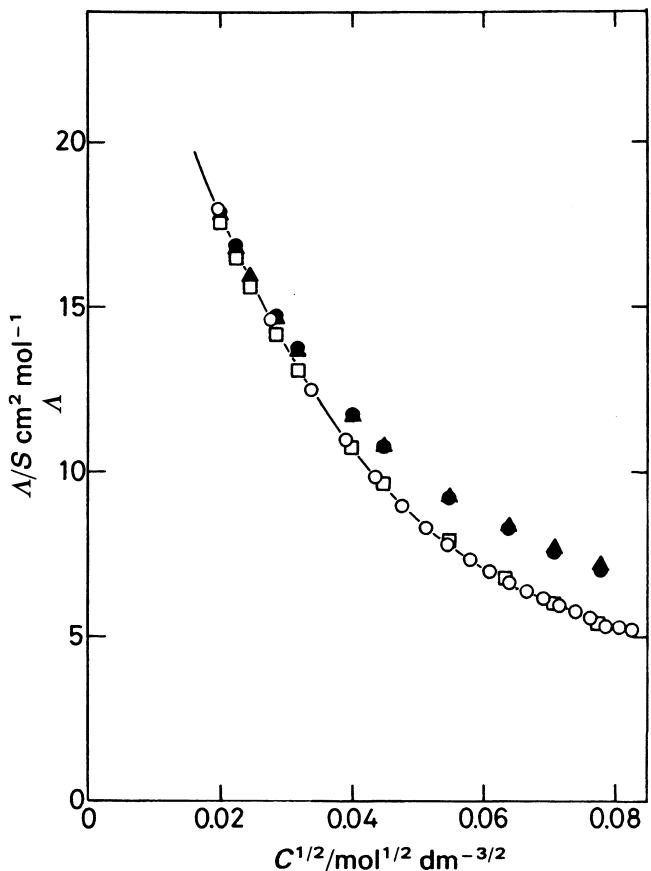

Fig. 8 Observed and calculated $\Lambda$ values of lithium trifluoroacetate $\left[(0.4 \sim 6.0) \times 10^{-3} \mathrm{M}\right]$ in PC: $(\bigcirc)$ observed; ( ) calculated with only ion-pair formation: (A) calculated with ion-pair and (weak) triple-ion formation: ( $\square$ ) calculated with ion-pair, (weak) triple-ion, and (strong) quadrupole formation

の生成を示唆している. 後にJansen $ら^{38)}$ は, PC 中のトリ フルオロ酢酸リチウム等について, 精密な導電率データを 提示したが，それを，Fuoss-Hisa 式で解析を試みたものの 失敗に終わり，この塩は溶液中では様々なイオン会合種を 生成していると結論付けた.

このように，高濃度になるとイオン対に加え，四重極子 (イオン対の二量体) の生成が著しくなる系をそのまま Shedlovsky 解析すると, $C \Lambda S f^{2}$ 対 $1 / \Lambda S$ の関係は直線では なく, Fig. 9 に示すように凹の曲線となり, 最小自乗法に よる直線の $\mathrm{Y}$ 切片の逆数から計算される限界モル導電率 $\Lambda_{0}$ の值は, 実際の值よりも大きな值となる. 強電解質に ついての Kohlrauschの法則からは $\Lambda_{0}\left(\mathrm{LiC}_{2} \mathrm{~F}_{5} \mathrm{COO}\right)=$ 24.03 となったが, Fig. 9 の解析からは, 44.86 という仮 想的な值（極めて高い值）が与えられた。このとき， $\mathrm{LiC}_{2} \mathrm{~F}_{5} \mathrm{COO} の \Lambda_{0}$ 值を求めるために利用した $\mathrm{LiClO}_{4}, \mathrm{Et}_{4}-$ $\mathrm{NC}_{2} \mathrm{~F}_{5} \mathrm{COO}$ 及び $\mathrm{Et}_{4} \mathrm{NClO}_{4}$ は「強電解質」であるか, 又は せいぜいイオン対を生成するだけであるが, $\mathrm{LiC}_{2} \mathrm{~F}_{5} \mathrm{COO}$ は高次イオン会合（この場合は四重極子生成）を引き起こ しているのである.ここで気付くことは，陽イオンが金属 イオンではなく, $\mathrm{Et}_{4} \mathrm{~N}^{+}$であれば，陰イオンがなんであれ， 「強電解質」となり, 一方, 㓌イオンが $\mathrm{ClO}_{4}{ }^{-}$であれば, 陽イオンが金属イオンであったとしても,「強電解質」と して作用することである。

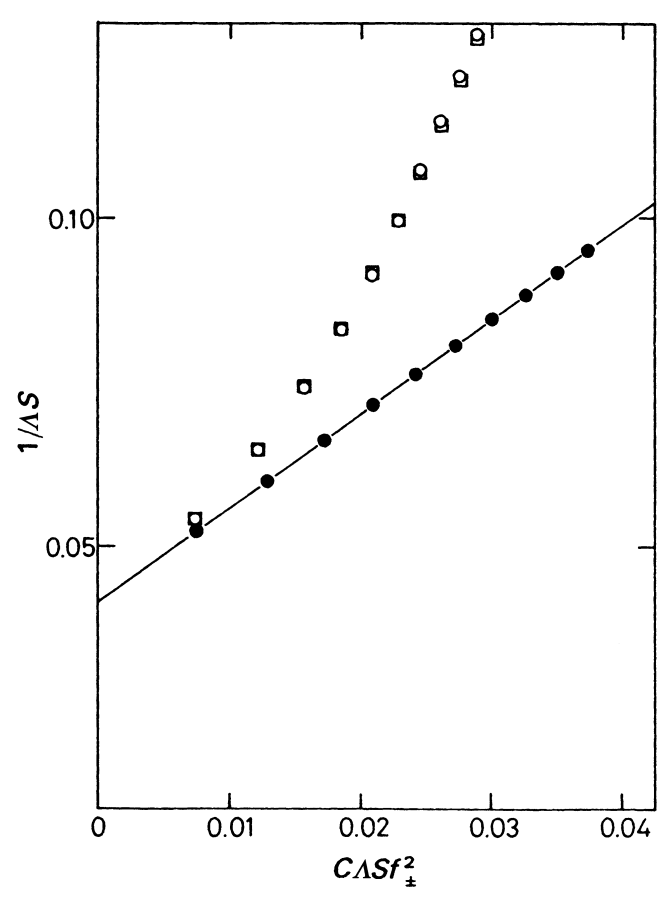

Fig. 9 Shedlovsky plots for $\mathrm{LiC}_{2} \mathrm{~F}_{5} \mathrm{CO}_{2}$ in PC: $(\bigcirc)$ experimentally observed points; $(\square)$ simulated points with ion-pair, triple-ion, and quadrupole formation;

(O) simulated points with ion-pair formation

イオン対に加え三重イオン生成が起こる場合には, Shedlovsky 解析の $C \Lambda S f^{2}$ 対 $1 / \Lambda S$ 関係は, 四重極子生成の ときとは反対に，凸型の曲線となる。それに従い，高濃度 側で傾斜が小さくなるため, 結果としての傾斜は小さく見 積もられることになる，極端な場合には，傾斜が小さくな るどころか，ほぼ水平にさえなることもあり（Fig. 10 参 照), この傾斜から計算される会合定数はゼロ $\left(K_{\mathrm{a}}=0\right)$ と算出されるため, 高次のイオン会合が著しく起こる（真 の）弱電解質でありながら, 誤って強電解質と見なしてし まうことがあり得る。

最も奇異に感じられることは，水溶液中 $\left(\varepsilon_{\mathrm{r}} \sim 80\right)$ で完 全解離する $\mathrm{LiCF}_{3} \mathrm{COO}$ 又は $\mathrm{LiC}_{2} \mathrm{~F}_{5} \mathrm{COO}$ が誘電率の高い $\mathrm{PC}$ 中 $\left(\varepsilon_{\mathrm{r}} \sim 65\right)$ で弱電解質に変貌してしまうことである. この点について Barthel ら ${ }^{39)}$ は, 著者らの研究を批判的に 評論している。ここでは, 発想を転換し, 疎プロトン性溶 媒である $\mathrm{PC}$ 中においては, $\mathrm{Li}^{+}$及び $\mathrm{CF}_{3} \mathrm{COO}^{-}$はもはや強 電解質を構成する要件を失っており，それぞれ水中での $\mathrm{H}^{+}$及び $\mathrm{CH}_{3} \mathrm{COO}^{-}$と同様の挙動をすると考えなくてなら ないようである。

MeCN 中で, $\mathrm{Li}^{+} \mathrm{PMBP}^{-}$(lithium 1-phenyl-3-methyl-4benzoyl-5-pyrazolonate：一種の $\beta$-ジケトン）の導電率曲線 上に極小を観測し，これらのモル導電率 $(\Lambda)$ を，三重イ オンを含む高次イオン会合によってほぼ定量的に説明した (Fig. 11 参照 $)^{40)}$ 。 三重イオンには $\mathrm{Li}^{+}\left(\mathrm{L}^{-}\right)_{2}$ 及び $\left(\mathrm{Li}^{+}\right)_{2} \mathrm{~L}^{-}$ 


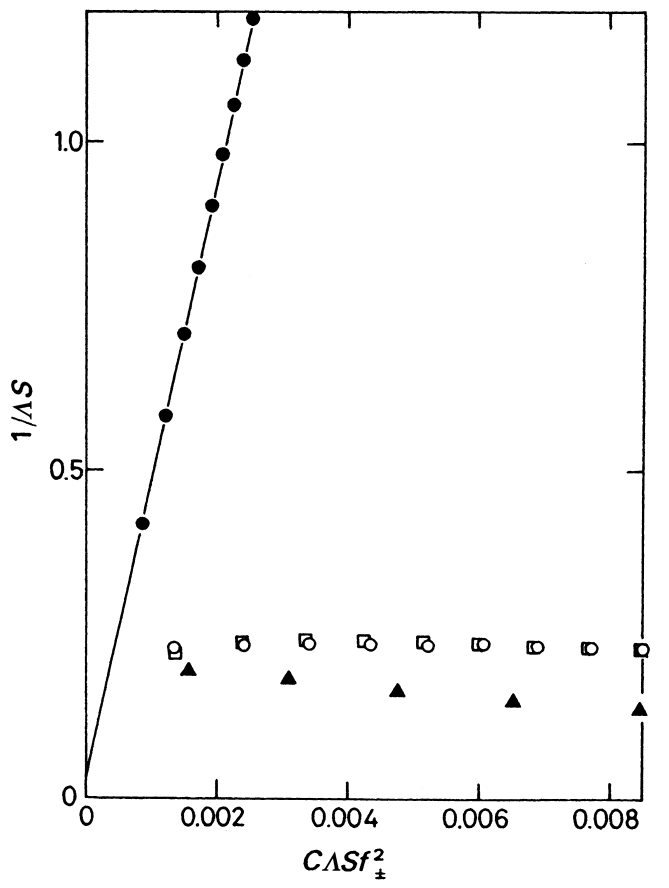

Fig. 10 Shedlovsky plots for $\mathrm{LiC}_{2} \mathrm{~F}_{5} \mathrm{CO}_{2}$ in $\mathrm{PhCN}$ : (○) experimentally observed points; $(\square)$ simulated points with ion-pair, triple-ion, and quadrupole formation ; $(\boldsymbol{\Delta})$ simulated points with ion-pair and triple-ion formation; (O) simulated points with ion-pair formation

の 2 種類あるが，その両者とも十分に生成しないと，極小 は出現しないことが計算された。 $\mathrm{Li}^{+}$の 4 配位錯体 $\mathrm{Li}^{+}\left(\mathrm{L}^{-}\right)_{2}$ 及び逆配位化学種 $\left(\mathrm{Li}^{+}\right)_{2} \mathrm{~L}^{-}$の生成を, それぞれ, ${ }^{7} \mathrm{Li} \mathrm{NMR}$ 及び紫外・可視吸収スペクトル法によって確認 した.

\section{$5 \cdot 4$ 水溶液中における酢酸分子の二量化}

ベンゼンや四塩化炭素のような非極性溶媒は，水素結合 性の弱い溶媒であり, その中で酢酸などのカルボン酸は, 水素結合力による二量化反応を引き起こすことはよく知ら れている，一方，極めて希薄な酢酸水溶液中では，多くの 酢酸分子がプロトン解離して, 酢酸イオンになっている上 に, 溶質一溶媒間の水素結合相互作用が強いので, 酢酸分 子が二量化することはほとんどあり得ない。しかし, 酢酸 濃度がある程度高くなると, 水溶液中においても酢酸分子 の二量化が起こり得ることは, 凝固点降下法, ラマンスペ クトル法又は蒸気圧測定法等の結果に基づき, 古くから示 唆されており，広範な研究がなされている ${ }^{41)}$. 鈴木らは, 水溶液中のカルボン酸類の二量化に及ぼす圧力効果を導電 度法で測定している ${ }^{42)}$.

導電率データから得られる酢酸の解離定数は, DebyeHückel 理論による活量係数の補正が有効である濃度範囲 で測定したにもかかわらず，高濃度側では，低濃度におけ

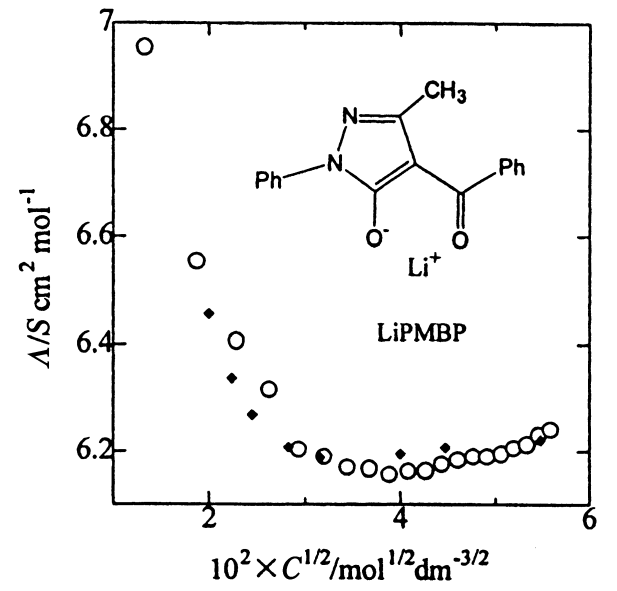

Fig. $11 \Lambda-C^{1 / 2}$ plots of lithium 1-phenyl-3-methyl-4benzoyle-5-pyrazolone (LiPMBP) in $\mathrm{MeCN}$ at $25^{\circ} \mathrm{C}$ : $(\bigcirc)$ observed; $(\diamond)$ calculated with ion-pair, triple-ion, and quadrupole formation

る測定值の外挿值から逸脱してしまうことが知られてい る.この現象は, 酢酸濃度増加に伴う誘電率の変化や非解 離酢酸分子による酸解離に対する「medium effect」等に よって説明されたりした。しかし, Katchalsky ら ${ }^{43)}$ は導電 率デー夕の緻密な解析を基に, 解離定数の変動は, 水溶液 中における酢酸分子の二量化に基づくと主張した。本研究 では, Katchalskyらの解析した導電率データ ${ }^{44)}$ をそのまま 著者らの解析法によって再解析する. 水溶液中においても 酢酸濃度が比較的高くなってくる $(<0.05 \mathrm{M})$ と二量体 （四重極子）生成反応が進行するために，上に述べた非水 溶媒中でなく水溶液中においても電解質の導電率の解析に 破綻が生じてしまうのであるが，その機構（からくり）を 解き明かしたい ${ }^{45)}$.

ここで用いた解析法の概略を次に示すが，酢酸を HX と表記し，電荷は省略することにする.

$$
\begin{aligned}
& \mathrm{H}+\mathrm{X} \Longleftrightarrow \mathrm{HX} ; K_{1}=[\mathrm{HX}] /([\mathrm{H}][\mathrm{X}]) \\
& 2 \mathrm{HX} \Longleftrightarrow \mathrm{H}_{2} \mathrm{X}_{2} ; K_{41}=\left[\mathrm{H}_{2} \mathrm{X}_{2}\right] /[\mathrm{HX}]^{2}
\end{aligned}
$$

プロトンについての質量均衡は, 酢酸の全濃度を $C_{\mathrm{s}}$ と すると，

$$
C_{\mathrm{s}}=[\mathrm{H}]+[\mathrm{HX}]+2\left[\mathrm{H}_{2} \mathrm{X}_{2}\right]
$$

であり，式（３）に式(1）及び（2）を代入し，整理する と式(4) が得られる.

$$
2 K_{41} K_{1}^{2}[\mathrm{X}]^{4}+K_{1}[\mathrm{X}]^{2}+[\mathrm{X}]-C_{\mathrm{s}}=0
$$

$[\mathrm{H}]=[\mathrm{X}]$ であるから, モル導電率と $C_{\mathrm{s}}$, 平衡イオン濃 
Table 1 Molar conductivities $\left(\Lambda / S \mathrm{~cm}^{2} \mathrm{~mol}^{-1}\right)$ of acetic acid in water at $25^{\circ} \mathrm{C}$ observed by MacInnes and Shedlovsky ${ }^{\text {a) }}$ and the relative error in the calculated $\Lambda$ values by our analytical method

\begin{tabular}{cccc}
\hline $\begin{array}{c}\text { Total concn. } \\
10^{3} \times \mathrm{C} / \mathrm{M}\end{array}$ & $\Lambda / S \mathrm{~cm}^{2} \mathrm{~mol}^{-1}$ & Rel. error $/ \%^{\mathrm{b})}$ & Rel. error $/ \%^{\mathrm{c})}$ \\
\hline 0.028014 & 210.32 & +0.01 & +0.01 \\
0.11135 & 127.71 & -0.02 & -0.03 \\
0.15321 & 112.02 & +0.10 & +0.10 \\
0.21844 & 96.466 & +0.05 & +0.05 \\
1.02831 & 48.133 & +0.05 & +0.03 \\
1.36340 & 42.215 & -0.01 & -0.03 \\
2.41400 & 32.208 & +0.05 & +0.01 \\
3.44065 & 27.191 & +0.06 & +0.01 \\
5.91153 & 20.956 & +0.07 & -0.02 \\
9.8421 & 16.367 & +0.10 & -0.05 \\
12.829 & 14.371 & +0.23 & +0.03 \\
20.000 & 11.563 & +0.33 & +0.02 \\
50.000 & 7.356 & +0.076 & -0.00 \\
52.303 & 7.200 & +0.70 & -0.10 \\
100.00 & 5.200 & +1.49 & -0.01 \\
119.447 & 4.759 & +1.65 & -0.13 \\
200.000 & 3.650 & +2.94 & +0.06 \\
230.785 & 3.391 & +3.30 & +0.01 \\
\hline
\end{tabular}

a) Ref. 43); b) Calculated with $K_{1}$ alone; c) Calculated with $K_{1}=5.0745 \times 10^{4}$ and $K_{41}=0.17$

度 $[\mathrm{X}]$ 及び限界モル導電率の補正值 $\Lambda_{0}^{\prime}$ の関係は式 $(5)$ である。

$$
\Lambda=\Lambda_{0}{ }^{\prime}[\mathrm{X}] / C_{\mathrm{s}}
$$

限界モル導電率 $\Lambda_{0}$ の補正には Onsager の極限式 $\left(\Lambda_{0}{ }^{\prime}=\right.$ $\left.\Lambda_{0}-\left(\alpha \Lambda_{0}+\beta\right) \sqrt{I}\right)$ を用いた。 ここで $\alpha, \beta$ 及び $I$ は，そ れぞれ緩和効果, 電気泳導効果に関する項及びイオン強度 である．測定濃度領域のすべての測定 $\Lambda$ 值を満たすよう な式 (4) における $K_{1}$ 及び $K_{41}$ の最適值を計算を繰り返す ことにより見いだした。なお，当然のことながら DebyeHückel 式により，イオン種について活量係数の補正を行 った.

Table 1 に, MacInnes ら ${ }^{44)}$ によって測定された導電率 データ及び著者らの解析法により解析した計算值の実測值 に対する誤差を\%単位で示している。（1：1）会合定数 $K_{1}$ (Katchalsky ら ${ }^{43)}$ による解離定数 $1.753 \times 10^{-5}$ の逆数: $K_{1}=5.7045 \times 10^{4}$ 及び $\Lambda_{0}=390.59^{44)}$ をそのまま利用した） により導電率を説明しようとすると, 酢酸濃度 $0.02 \mathrm{M}$ 以 上では，計算による予想導電率よりも実測導電率は明らか に低くなる．ここで $K_{1}$ に加えて, 二量化定数 $K_{41}=0.17$ 導入すると， $\pm 0.1 \%$ 程度の誤差範囲で, 酢酸濃度 $2.8 \times$ $10^{-5} \sim 0.23 \mathrm{M}$ 範囲の全測定值を説明することができた. なお，Katchalskyらは二量化定数として 0.16 を与えてい る.ここで得られた会合定数及び二量化定数を用いて計算

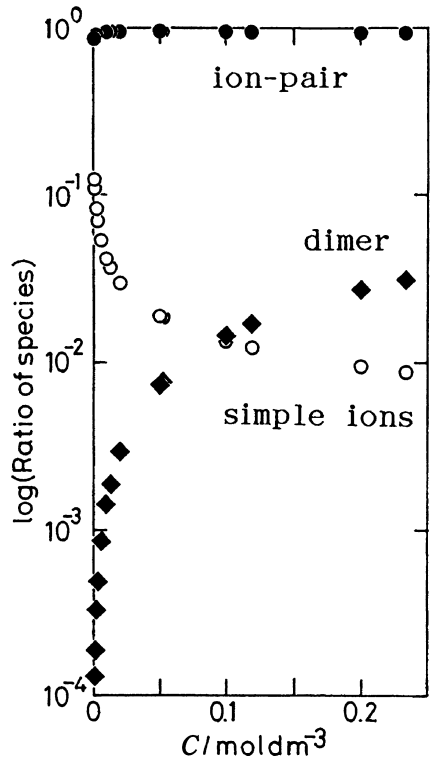

Fig. 12 Changes of equilibrium concentrations of each species with the $\mathrm{CH}_{3} \mathrm{COOH}$ concentration in $\mathrm{H}_{2} \mathrm{O}$ calculated with $K_{1}=5.7045 \times 10^{4}$ and $K_{41}=0.17$ : (O) simple ions, $\left[\mathrm{H}^{+}\right]=\left[\mathrm{CH}_{3} \mathrm{COO}^{-}\right] ;(\bigcirc)$ the ion pair, $\left[\mathrm{CH}_{3} \mathrm{COOH}\right] ;(\diamond)$ the dimer, $\left[\left(\mathrm{CH}_{3} \mathrm{COOH}\right)_{2}\right]$

すると, 各化学種の平衡濃度の割合は, Fig. 12 に示すよ うになった。低濃度分は一部省略しているが，示された全

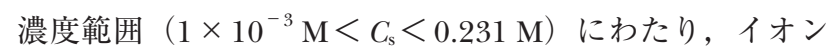
対 (酢酸分子) が大部分を占める. 酢酸濃度の増加に伴い, 単イオン $([\mathrm{H}]=[\mathrm{X}])$ が減少する代わりに二量体 $\left(\left[\mathrm{H}_{2} \mathrm{X}_{2}\right]\right)$ が増加しており, $0.1 \mathrm{M}$ 付近で単イオンよりも 二量体が優先するようになることが分かる.

水溶液中の酢酸は, $1: 1$ 型イオン会合に加えて二量体 (四重極子) の生成を引き起こすので，1:1型イオン会合 だけを想定した理論式は，いかに精密な理論式であって も, PC 中のリチウムトリフルオロ酢酸等の場合と同じよ うに，破綻するであろう. Shedlovsky 法 $^{36)}$ は, 高次項の一 部だけを組み入れただけのそれほど精度の高い理論式とは いえないが，適用範囲が広いのでよく利用されている。 Table 1 の導電率データを, Shedlovsky 法によって解析 し，見掛けの限界モル導電率 $\Lambda_{0}$ と会合定数 $K_{\mathrm{a}}$ を計算する と，上で予想した結果が得られた。すなわち，二量体の生 成を考虑しなくてもよいような低濃度側のデータだけの解 析結果と高濃度側デー夕も含んで解析した結果には，大き な違いができた。サンプリングポイント $1 \sim 8,1 \sim 12$, $1 \sim 16$ 及び $1 \sim 18$ について, 見掛けの $\Lambda_{0}$ 值は, それぞれ, 391.28，402.51，542.69 及び 1046.2 と著しく増大した. この間，見掛けの $K_{\mathrm{a}}$ 值は $5.73 \times 10^{4}$ から $4.24 \times 10^{5}$ まで 増加した。

Katchalsky らによる解析法 ${ }^{43)}$ は，1:1 型イオン会合とそ の二量化反応が共に起こる系の解析に有効である。また, 
Fuoss-Kraus の解析法 ${ }^{29)}$ は, $1: 1$ 型イオン会合に加えて三 重イオン生成のみが起こるときにうまく利用できる。しか し, どちらの解析法も, 三重イオン生成と二量化反応の両 方が進行するときに利用できるようには設計されていな い.ここでは詳しく述べないが, 上記の式(4) に三重イ オンの項を加え一般化した著者らの解析法 ${ }^{20) 34(35) 40)}$ は, 彼 らの解析法とは根本的に異なり, $1: 1$ 型イオン会合, 三 重イオン生成及び二量化（四重極子生成）反応が同時に起 こるときにも解析可能である。この解析法の開発により, 溶液中の高次イオン会合状態を, 従来とは異なり格段に詳 しく理解できるようになったといえる.

$6 \mathrm{M}^{+}$及び $\mathrm{M}^{2+}$ と塩基又は陰イオン間の化学的相互 作用

\section{$6 \cdot 1$ 酸塩基又は金属指示薬等に及ぼす塩効果}

陽イオン及び陰イオンの両者に対して溶媒和力が弱い疎 プロトン性溶媒中では, 電荷が球対称的に分散している $\mathrm{ClO}_{4}{ }^{-}$などを除く多くの陰イオンは，アルカリ金属 $\left(\mathrm{M}^{+}\right)$ 又はアルカリ土類金属イオン $\left(\mathrm{M}^{2+}\right)$ と予想以上に大きな 相互作用をする。

ローダミン B base（この場合 HCl は結合していない） に $\mathrm{MClO}_{4}$ 及び $\mathrm{M}\left(\mathrm{ClO}_{4}\right)_{2}$ を添加すると, 溶液内反応によ り，分子内 $\gamma$-ラクトン環 (C-O) が切断されることが分か った。クリスタルバイオレット・ラクトンの開環に対して は, カルボン酸イオンとの結合力の強い $\mathrm{Mg}^{2+}$ だけが有効 であった ${ }^{46)}$. 金属イオン添加によるフェノールレッド，ブ ロモチモールブルー等の sulfonephthalein 系指示薬の発色 の変化は, 金属イオンとスルホン酸イオン間の化学的相互 作用に基づく $\gamma$-スルトンの開環によるものであると結論 した ${ }^{47)}$. ローダミン B base と同じょうに，フルオラン骨 格を持つ黒色発色色素は, $\mathrm{MeCN}$ 中でアルカリ金属又は アルカリ土類金属イオンと反応して，発色することが確認 された ${ }^{48)}$.

$\mathrm{MeCN}$ 中で, 酸塩基指示薬「メチルイエロー」\{p(dimethylamino)azobenzene\}を用いて测定した Hammett の酸度関数 $H_{\mathrm{o}}$ ( $\mathrm{pH}$ に対応）は, 塩を共存させ ると大きく変動してしまうことを見いだした ${ }^{49)}$. この塩効 果は，プロトン化した指示薬（Ind）上の $\mathrm{H}^{+}$と大過剩に 共存する金属イオンとのイオン交換反応 $\{$ 式 (6) $\}$ 及び, ホモ共役反応を伴う脱プロトン化反応 $\{$ 式 $(7)\}$ によっ て説明された。

$$
\begin{aligned}
& \text { Ind }-\mathrm{H}^{+}+\mathrm{M}^{+} \rightleftarrows \text { Ind-M } \mathrm{M}^{+}+\mathrm{H}^{+} \\
& \text {Ind }-\mathrm{H}^{+}+2 \mathrm{X}^{-} \Longleftrightarrow \text { Ind }+\mathrm{HX}_{2}{ }^{-}
\end{aligned}
$$

水溶液中におけるキレート滴定の金属指示薬としてょく 使用される PAN 1 1-(2-pyridylazo)-2-naphthol $\}$ は，水溶液
中でアルカリ土類金属イオンとは明確な錯形成をしないと されている，しかし， MeCN中では，PAN 分子と $\mathrm{Mg}^{2+}$ 間 で脱プロトンを伴う明確な錯生成反応が観測された。また PAN の誘導体である 2-(5-bromo-2-pyridylazo)-5-diethylaminophenol 中のジェチルアミノ基と $\mathrm{Mg}^{2+}$ 間の相互作用 等も確認された ${ }^{50)}$.

$6 \cdot 22$ 種類のイオン対の生成:「接触イオン対」と「溶 媒介入イオン対」

$\mathrm{MeCN}$ 中で，七員環を有するトロポロン $\left(\mathrm{C}_{7} \mathrm{H}_{5} \mathrm{O}_{2} \mathrm{H}\right)$ とトリエチルアミン $\left(\mathrm{Et}_{3} \mathrm{~N}\right)$ 間のプロトン移動反応 ${ }^{51)}$ は, 共存するアルカリ金属 $\left(\mathrm{M}^{+}\right)$又はアルカリ土類金属イオ ン $\left(\mathrm{M}^{2+}\right)$ 過塩素酸塩によって大きく促進された。一方， $\mathrm{Et}_{4} \mathrm{NCl}$ の添加によって,「フリー」のトロポロンイオンが 生成した $\{$ 式 $(8)$ 及び（9）参照 $\} . \mathrm{Li}^{+}$と結合したトロ ポロンイオンはフリーのそれより短波長側に吸収バンドを 与えた。

$$
\begin{aligned}
\mathrm{C}_{7} \mathrm{H}_{5} \mathrm{O}_{2} \mathrm{H}_{-N E t_{3}}+ & 2 \mathrm{Li}^{+} \\
& \Longleftrightarrow \mathrm{C}_{7} \mathrm{H}_{5} \mathrm{O}_{2}{ }^{-}\left(\mathrm{Li}^{+}\right)_{2}+\mathrm{Et}_{3} \mathrm{NH}^{+} \\
\mathrm{C}_{7} \mathrm{H}_{5} \mathrm{O}_{2} \mathrm{H}-\mathrm{NEt}_{3}+ & 2 \mathrm{Cl}^{-} \\
& \Longleftrightarrow \mathrm{C}_{7} \mathrm{H}_{5} \mathrm{O}_{2}{ }^{-}+\mathrm{Et}_{3} \mathrm{NH}^{+}\left(\mathrm{Cl}^{-}\right)_{2}
\end{aligned}
$$

同溶媒中で，各種のニトロフェノールから塩基へのプロ トン移動反応に及ぼす塩効果が研究され, $\mathrm{MClO}_{4}$ 又は $\mathrm{M}\left(\mathrm{ClO}_{4}\right)_{2}$ の添加により, 金属イオンとフェノレートイオ ンが強く結合して「接触イオン対」 $\left[\left(\mathrm{NO}_{2}\right)_{2} \mathrm{C}_{6} \mathrm{H}_{3} \mathrm{O}^{-}\left(\mathrm{M}^{+}\right)_{2}\right.$, $\left.\left(\mathrm{NO}_{2}\right)_{2} \mathrm{C}_{6} \mathrm{H}_{3} \mathrm{O}^{-}\left(\mathrm{M}^{2+}\right)\right]$ (Fig. 13 参照) が生成する一方, $\mathrm{Et}_{4} \mathrm{NX}(\mathrm{X}=\mathrm{Cl}, \mathrm{Br})$ の添加によって,「フリー」のフェノ レートイオン $\left[\left(\mathrm{Et}_{4} \mathrm{~N}^{+}\right)---\left(\mathrm{NO}_{2}\right)_{2} \mathrm{C}_{6} \mathrm{H}_{4} \mathrm{O}^{-}\right]$又は「溶媒介 入イオン対」(Fig. 14) の生成が観測された ${ }^{52)}$.

7 ソルボリシス反応速度に及ぼす濃厚塩効果の解明

$7 \cdot 1 \quad \mathrm{M}^{+}$又は $\mathrm{M}^{2+}$ によるハロゲン化物イオンの引き抜 きによるカルボカチオンの生成

溶液中におけるカルボカチオンの安定化の問題は，有機 反応機構, 特にソルボリシスにおける $S_{\mathrm{N}} 1$ 及び $S_{\mathrm{N}} 2$ 反応 を考察する上で，たいへん重要である．幾つかの溶媒，例 えば $\mathrm{SO}_{2}$ 中で triphenylmethyl chloride (trityl chloride, $\left.\mathrm{Ph}_{3} \mathrm{CCl}\right)$ はイオン化するが， $\mathrm{MeCN}$ 中では，ほとんどイ オン化していない. $\mathrm{HgCl}_{2}, \mathrm{AlCl}_{3}$ 及び $\mathrm{SnCl}_{4}$ 等の金属塩化 物を添加すると，トリチルカチオン $\left(\mathrm{Ph}_{3} \mathrm{C}^{+}\right)$が定量的に 生成することが知られている ${ }^{53)}: \mathrm{Ph}_{3} \mathrm{CCl}+\mathrm{MCl}_{m} \leftrightarrows$ $\mathrm{Ph}_{3} \mathrm{C}^{+}+\left[\mathrm{MCl}_{m+1}\right]^{-}$. $\mathrm{MeCN}$ 中で, $\mathrm{Ph}_{3} \mathrm{CX}(\mathrm{X}=\mathrm{Cl}, \mathrm{Br})$ に $\mathrm{MClO}_{4}(\mathrm{M}=\mathrm{Li}, \mathrm{Na})$ 及び $\mathrm{M}\left(\mathrm{ClO}_{4}\right)_{2}(\mathrm{M}=\mathrm{Mg}, \mathrm{Ca}, \mathrm{Sr}, \mathrm{Ba})$ を添加すると, $\mathrm{Ph}_{3} \mathrm{C}^{+}$が生成することを, 紫外・可視吸収 スペクトルにより見いだした ${ }^{46)}$.4-MeO-置換したトリチ 


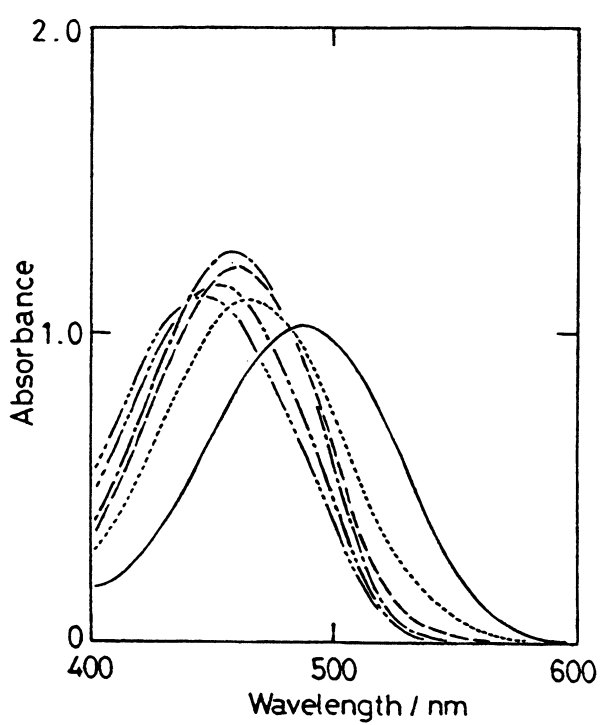

Fig. 13 Changes of visible absorption spectra of 2,5dinitrophenolate $\left(\left[\mathrm{Et}_{4} \mathrm{~N}^{+} 2,5-\left(\mathrm{NO}_{2}\right)_{2} \mathrm{C}_{6} \mathrm{H}_{3} \mathrm{O}^{-}\right]=2.0 \times\right.$ $\left.10^{-4} \mathrm{M}\right)$ with increasing concentration of $\mathrm{Li}^{+}$in $\mathrm{MeCN}$ : (-) 0 ; (-----) $1.0 \times 10^{-4} ;(---) 2.0 \times 10^{-4} ;(-\cdot-\cdot)$ $5.0 \times 10^{-4}$ and $1.0 \times 10^{-3} ;(-\cdot-) 0.1 ;(-\cdots-) 0.2 \mathrm{M}$ $\mathrm{LiClO}_{4}$

ルクロリド (4- $\left.\mathrm{MeOC}_{6} \mathrm{H}_{4}\right)_{n} \mathrm{Ph}_{3-n} \mathrm{CCl}(n=1 \sim 3)$ に上記の 金属過塩素酸塩を添加すると, 相当するトリチルカチオン が生成したが，これらの反応は ${ }^{1} \mathrm{H}$ 及び ${ }^{13} \mathrm{C} \mathrm{NMRにおける}$ ケミカルシフトの変化よっても確認でき ${ }^{48) 54)}$, 更に過塩素 酸トリチル類の合成に利用された ${ }^{54)}$.

ところで, 比較的高濃度の塩化トリチル類に金属イオン を添加すると $\mathrm{Li}^{+}$及び $\mathrm{Mg}^{2+}$ を除くすべての金属イオンに ついて沈殿が生じた.ここで, $\mathrm{Ba}^{2+}$ からの沈殿は, $\mathrm{BaCl}_{2}$ ではなく, $\mathrm{BaCl}^{+} \mathrm{ClO}_{4}{ }^{-}$（溶解度： $\mathrm{MeCN}$ 中 $25^{\circ} \mathrm{C}$ で約 $\left.2.0 \times 10^{-3} \mathrm{M}\right)$ であることが, 組成分析, IR, X 線粉末法 及び熱分析法によって確認された ${ }^{55)}$.

\section{$7 \cdot 2 S_{\mathrm{N}} 1$ 及び $S_{\mathrm{N}} 2$ 反応基質}

上記のように, MeCN中のアルカリ金属又はアルカリ 土類金属イオンには, $\mathrm{C}-\mathrm{X}$ 結合から $\mathrm{X}^{-}$を引き抜く能力の あることが示された.ここで水溶液又は有機溶媒一水混合 溶媒系中等においても, アルカリ金属イオン等と単純な陰 イオン間の化学的相互作用を観測できるのであろうかとい う疑問がわいてくるかもしれない. 常温, 常圧下の水溶液 中では強く溶媒和を受けるため, これらのイオンが直接関 与する化学反応平衡を観測することは容易ではない. しか し, 反応速度を利用すると, (平衡反応では) とうてい観 測できない程度の微少な反応中間体濃度の増加を繰り返し 蓄積していく結果, 観測可能な反応速度の変化量として計 測できるようになることが期待できる.

$\mathrm{MeOH}-\mathrm{H}_{2} \mathrm{O}$ 混合溶媒中において, adamantyl bromide

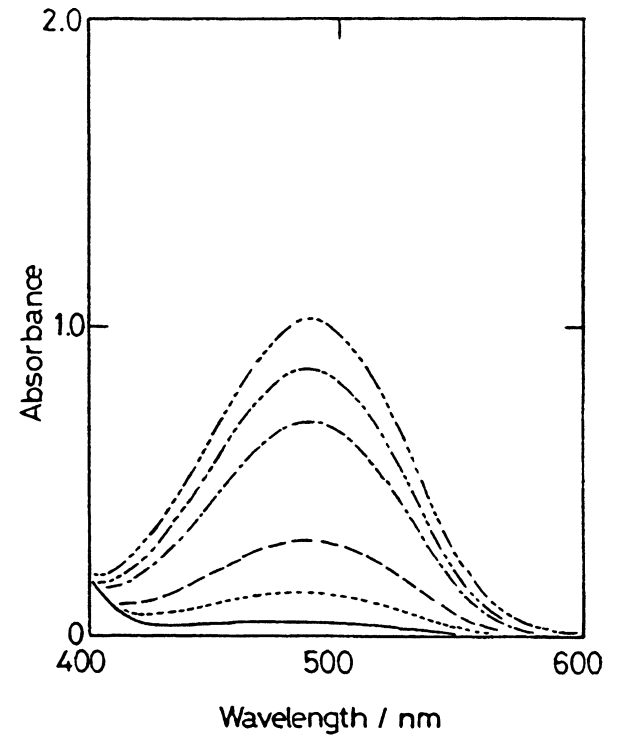

Fig. 14 Production of free 2,5-dinitrophenolate ions by the addition of various concentrations of $\mathrm{Et}_{4} \mathrm{NCl}$ to $2.0 \times 10^{-4} \mathrm{M}$ 2,5-dinitrophenol $+2.0 \times 10^{-3}$ 2-chlorobenzylamine in MeCN: $(-) 0 ;(-\cdots--) 1.0 \times 10^{-3}$; $(---) 1.0 \times 10^{-2} ;(-\cdot-\cdot) 0.1 ;(-\cdot-) 0.2 ;(-\cdot-) 0.3$ $\mathrm{M} \mathrm{Et}{ }_{4} \mathrm{NCl}$

及び $t$-butyl chloride 等の典型的な $S_{\mathrm{N}} 1$ 基質に高濃度の $\mathrm{LiClO}_{4}$ を共存させると, ソルボリシス反応の擬一次反応 速度が，指数関数的に増加した ${ }^{56)}$. $\mathrm{Na}^{+}$の効果は, $\mathrm{Li}^{+}$の それより小さかったが, $\mathrm{Mg}^{2+}$ 及び $\mathrm{Ba}^{2+}$ の効果はょり大き かった.これら金属イオンの効果は, 濃厚塩共存による溶 媒構造の変化及びその中におけるハロゲン化物イオンと金 属イオン間の化学的相互作用によって説明された (Scheme 4 参照).

isopropyl bromide 及び benzyl chloride 等の $S_{\mathrm{N}} 1-S_{\mathrm{N}} 2$ 中間基質に対しては，金属イオン添加による速度上昇は， 見掛け上ほとんど観測されなかった。逆に，alkyl bromide 等の $S_{\mathrm{N}} 2$ 基質のソルボリシス反応速度は, 金属過塩素酸 塩添加により低下した。 アセトン $-\mathrm{H}_{2} \mathrm{O}^{57)}$ ，ジオキサン$\mathrm{H}_{2} \mathrm{O}^{58)}$ ，アセトニトリル $-\mathrm{H}_{2} \mathrm{O}, \mathrm{DMF} \mathrm{H}_{2} \mathrm{O}$ 及びスルホラ ン $-\mathrm{H}_{2} \mathrm{O}$ 溶媒系についても同様の結果が得られている.

8 水構造性の変化と「二水素エーテル」の生成

\section{$8 \cdot 1$ 濃厚塩及び有機溶媒の添加による水構造の変化}

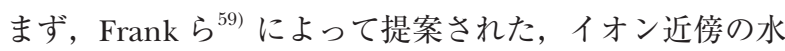
の構造について説明しておきたい. 水に塩を溶解させる と, イオンの周りに 3 種類の異なる領域が生成すると考 えられる。すなわち, $\mathrm{A}$ 領域: 水分子が固定された領域, $\mathrm{B}$ 領域：水の構造が破壊された領域, $\mathrm{C}$ 領域：正常な構造 をもつ領域（バルク水）である。例えば， $\mathrm{Li}^{+}$イオンは $\mathrm{B}$ 領域よりも $\mathrm{A}$ 領域の発達を促すので, 構造形成的なイオ ンに分類される. 逆に, $\mathrm{C}_{\mathrm{s}}{ }^{+}$による $\mathrm{A}$ 領域の発達は小さく, 


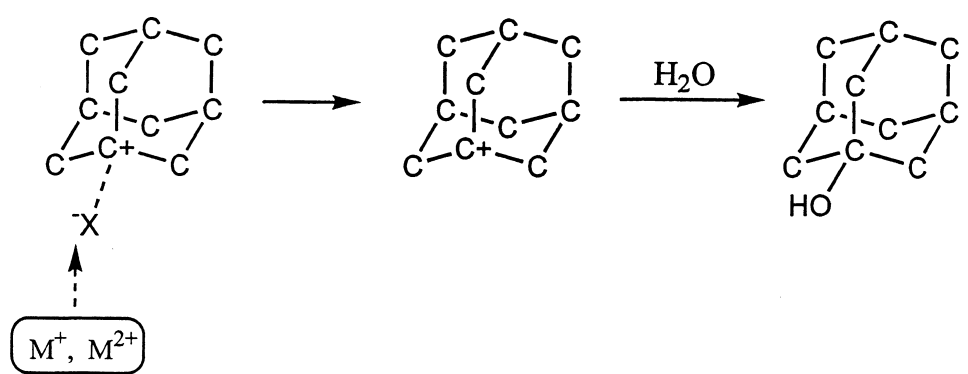

Scheme 4 The mechanism of the enhanced solvolysis (hydrolysis) reaction of the $S_{\mathrm{N}} 1$ substrate in the presence of alkali metal $\left(\mathrm{M}^{+}\right)$or alkaline earth metal ions $\left(\mathrm{M}^{2+}\right)$

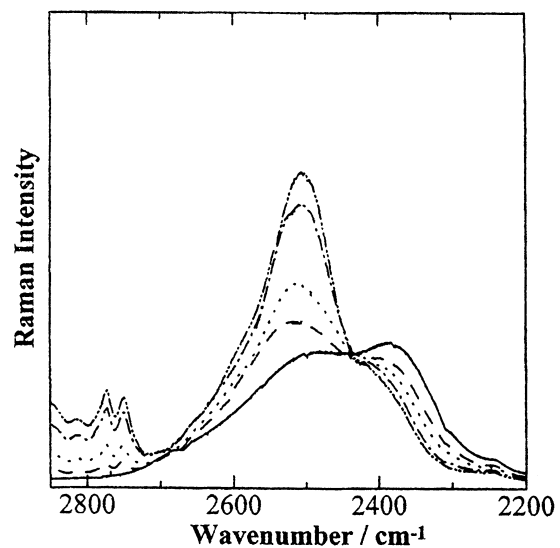

Fig. 15 The Raman spectra of $\mathrm{D}_{2} \mathrm{O}$ containing various amounts of $\mathrm{Et}_{4} \mathrm{NBr}$ at room temperature: ( $\square$ ) no salt; (---) $\mathrm{R}=20 ;(\cdot-\cdot-\cdot) \mathrm{R}=10 ;(-\cdot-\cdot) \mathrm{R}=5$; $(-\cdot-) \mathrm{R}=3.75$ where $\mathrm{R}=\left[\mathrm{D}_{2} \mathrm{O}\right] /\left[\mathrm{Et}_{4} \mathrm{NBr}\right]$

$\mathrm{C}_{\mathrm{s}}{ }^{+}$は構造破壊的イオンである。この議論は, 希薄溶液又 は比較的低濃度の塩溶液について適用できる．著者らは， 水溶液又は有機溶媒混合水溶液中に極めて高濃度の塩が存 在すると, C 領域が縮小ないし消滅すると示唆してき た $^{56)}$.このような極端な条件下では, 上記のモデルにおけ る B 領域（水の構造が破壊された領域）だけが有効な溶 媒機能を有すると考えられる。ここでは，水溶媒の性質が 変質し,「擬似アルコール」又は「擬似エーテル」すなわ ち, 著者らの命名による「二水素エーテル」([R] [H]-O$[\mathrm{H}][\mathrm{R}])^{58)}$ となっていると考えることができる.

Fig. 15 は, 室温における種々の濃度の $\mathrm{Et}_{4} \mathrm{NBr}$ を含む $\mathrm{D}_{2} \mathrm{O}$ のラマンスペクトルを示す．塩に対する水の量（ $R=$ $\left[\mathrm{D}_{2} \mathrm{O}\right] /\left[\right.$ 塩]）が減少するにつれて, $2390 \mathrm{~cm}^{-1}$ のバンド の強度が低下しながら, $2510 \mathrm{~cm}^{-1}$ 付近のバンドが増大し た。液体 $\mathrm{D}_{2} \mathrm{O}$ の $\mathrm{OD}$ 伸縮振動によるラマンスペクトルは 約 $2200 \mathrm{~cm}^{-1}$ から $2800 \mathrm{~cm}^{-1}$ に広がっており, そのピー クは約 $2510 \mathrm{~cm}^{-1}$ であることが報告されている ${ }^{60)}$. 本研究 における $\mathrm{Et}_{4} \mathrm{NBr}$ の $R=20$ におけるラマンスペクトルは, 吉村ら ${ }^{60)}$ よって観測された $\mathrm{D}_{2} \mathrm{O}$ 中 $\mathrm{Et}_{4} \mathrm{NCl}$ の $R=16$ にお
けるラマンスペクトルによく似ている。 $-10 \sim 90{ }^{\circ} \mathrm{C}$ の液 体 $\mathrm{D}_{2} \mathrm{O}$ のラマンスペクトルは，温度の上昇に伴い， 2400 $\mathrm{cm}^{-1}$ 付近のバンド強度が減少する代わりに, $2500 \mathrm{~cm}^{-1}$ 当たりのバンドが増大することを Scherer ら ${ }^{61)}$ は報告して いる.これらのバンドは, $\mathrm{D}_{2} \mathrm{O}$ 分子の対称的な（又は両 方の) 水素結合「錯体」 $\left(2400 \mathrm{~cm}^{-1}\right)$ と片方だけの水素結 合「錯体」(2500 $\left.\mathrm{cm}^{-1}\right)$ による OD 伸縮振動に起因してい るとされた。いずれにしても，温度上昇による液体 $\mathrm{D}_{2} \mathrm{O}$ の水素結合の（部分的）破壊は $2500 \mathrm{~cm}^{-1}$ 付近のバンド 強度の増大を促進するのである。したがって，本研究にお ける $\mathrm{Et}_{4} \mathrm{NBr}$ 濃度増加によるスペクトルの変化は，水素結 合の切断に起因すると結論できる. 濃厚塩共存による水素 結合の切断により, $\mathrm{D}_{2} \mathrm{O}$ の大きなクラスターは，より小 さなクラスターへと変化すると考えられる.

ところで, Brink ら ${ }^{62)}$ は， $28^{\circ} \mathrm{C}$ における異なる濃度の $\mathrm{NaClO}_{4}$ 及び $\mathrm{Mg}\left(\mathrm{ClO}_{4}\right)_{2}$ 水溶液中の $\mathrm{HDO}$ の（IR スペクト ルにおける） OD 伸縮振動吸収帯を報告している．塩が共 存していない場合の $2500 \mathrm{~cm}^{-1}$ の吸収帯（水素結合した HDO の OD 伸縮）は塩濃度の増加に伴い, 高波数帯（約 $2620 \sim 2630 \mathrm{~cm}^{-1}$ ) に変化していった。この観測結果に対 して, Verrall ${ }^{63)}$ は次のようにコメントしている。「高波数 側の吸収帯は $\mathrm{ClO}_{4}{ }^{-}$イオンによる水素結合の破壊によるも のであり，温度上昇によるスペクトル変化と類似してい る」.

四級アンモニウムイオン $\left(\mathrm{R}_{4} \mathrm{~N}^{+}\right)$は，その「疎水的効 果」により，イオン径から期待されるよりも大きな構造形 成的性質を示すと考えられてきた。しかし，20 vol\% EtOH- $\mathrm{H}_{2} \mathrm{O}$ 中で測定した結果ではあるが， $\mathrm{R}_{4} \mathrm{~N}^{+}$はむしろ 水の構造性を破壊する傾向であることが分かり，しかもア ルキル鎖の長いほうが，むしろ構造破壊性の強いことがプ ロトン NMR の化学シフト值の変化から示された ${ }^{64)}$. とも あれ, 水和部分 (A 領域) ではなく, 溶媒部分 $(\mathrm{B}$ 及び $\mathrm{C}$ 領域）を観測するためには， $\mathrm{Et}_{4} \mathrm{NBr}$ は最適な塩の一つで あると思われる。なぜなら，水溶液中において， $\mathrm{Et}_{4} \mathrm{~N}^{+}$及 び $\mathrm{Br}^{-}$は，共に強い水和を受けることがない上に，水に対 
する溶解度が室温でも非常に大きいからである. Verrall ${ }^{63)}$ もまた，構造効果と関連付けるには， $\mathrm{R}_{4} \mathrm{NBr}$ 類は適当な 塩であると述べている，ここで， $\mathrm{D}_{2} \mathrm{O}$ は $\mathrm{H}_{2} \mathrm{O}$ よりもより 構造性の高い液体であること㬏を認めながらも, 上記の $\mathrm{D}_{2} \mathrm{O}$ についての議論は，そのまま $\mathrm{H}_{2} \mathrm{O}$ 及び $\mathrm{H}_{2} \mathrm{O}$ - 混合溶 媒にも適用できると思われる。

濃厚な $\mathrm{LiBr}$ を含む $\mathrm{D}_{2} \mathrm{O}$ のラマンスペクトルは, 塩濃度 の増加に伴い, 約 $2390 \mathrm{~cm}^{-1}$ にかわり, $2530 \mathrm{~cm}^{-1}$ 付近の バンドの大きな増加をもたらした。 $\mathrm{LiBr}$ 塩の場合には, ラマンバンド中に, バルク水からシグナルに加えて $\mathrm{Li}^{+} に$ 対する水和効果が含まれているはずである. $\mathrm{Et}_{4} \mathrm{~N}^{+}$の場合 $\left(2510 \mathrm{~cm}^{-1}\right)$ とは波数が幾分異なっているのは, $\mathrm{Li}^{+}$に対 する強い水和が関係しているためであると思われる.

$\mathrm{D}_{2} \mathrm{O}$ に対して DMF やスルホランのような有機溶媒を混 合させると, やはり水の水和構造は低下する.これらの有 機溶媒一水混合溶媒に $\mathrm{Et}_{4} \mathrm{NBr}$ 又は $\mathrm{LiClO}_{4}$ を添加すると, 水の構造が更に低下ないし破壊されることが示された。こ のように, 共存する他の溶媒又は濃厚塩により, 水そのも のの特性が変化し, 溶媒機能がもとの「バルク水」のそれ とは異なり, むしろ「二水素エーテル」すなわち非水溶媒 に近いものに変化しているように思える。

\section{$8 \cdot 2$ 微小水滴中, 高温下又は界面など}

逆ミセル中, すなわち有機溶媒中の微小水滴 (nm オー ダー）は，塩を添加することにより，水としての特性を更 に失うことが明瞭に示された ${ }^{66)}$. クロロホルム中で陽イオ ン性界面活性剤であるセチルトリメチルアンモニウムブロ ミド又はクロリド等が形成する逆ミセル $\left[\mathrm{CHCl}_{3} / \mathrm{CTAB}\right.$, $\left.\mathrm{CTAC} / \mathrm{H}_{2} \mathrm{O}(1.0 \mathrm{vol} \%)\right]$ の微小水滴に $\mathrm{CoCl}_{2}$ 又は $\mathrm{CoBr}_{2}$ を溶解させると, 無色に近いままであるが, そこに $\mathrm{LiClO}_{4}$ 等の塩を添加すると, $\left[\mathrm{CoX}_{4}\right]^{2-}$ の生成量が増加し て, 溶液は青色に変化する。このような 4 配位のコバル 卜錯体の生成は, その場の䨌囲気が乾燥又は無水条件下で あることを示唆している。このようなバルク水の特性を完 全に失った場を，そのまま水溶液の概念で取り扱うと問題 の本質を見失う可能性が出てくる. 系は少し異なるが, Bjerrum $ら^{67)}$ は, $\left[\mathrm{CoCl}_{4}\right]^{2-}$ の全生成定数として, イオン 強度 0 及び $9 \mathrm{M} \mathrm{HClO}_{4}$ の水溶液中でそれぞれ $10^{-6.6}$ 及び $10^{4}$ と報告し, この $1.5 \times 10^{10}$ 倍の増加をイオンの活量係 数の増加に帰し， $\gamma_{ \pm} \sim 350$ とすれば説明できると記述し ている.

ところで, 高温・高圧の超臨界状態では, 水の水素結合 はほとんど切れているとされた ${ }^{68)}$. しかし, 気相中の水分 子でさえ二量体以上の多量体を生成することができる ${ }^{5)}$ であるから, 低圧の気相に比べると密度が著しく高い超臨 界水中では, 水素結合が残存すると考えるほうが自然であ ろうと思われる. ともかく超臨界水中の水の構造性は著し
く破壊され，水としての特性は大幅に失われていると思わ れる. 超臨界水中において, 高濃度の $\mathrm{NaCl}$ からのイオン 多重体生成が示唆されている ${ }^{69)}$.

バルク水の性質は，水素結合による水分子の大集団化に より発現すると考えられるので, 水の大集団化が起こり得 ないような状況下では，バルク水の性質は見なれなくなる はずである。どのようなときにバルク水としての特性が失 われる可能性があるかをまとめておきたい.（a）有機溶媒 中の残余水 $\left(\sim 10^{-3} \mathrm{M}\right)$,（b）濃厚塩を含有する水溶液又 は非水溶媒一水混合溶液，（c）ナノチューブ又は逆ミセル 中のナノサイズ微小水滴中（水の分子数 $n_{\mathrm{w}}<\sim 10^{7}$ ), (d) 電極の金属板，イオン交換樹脂，溶媒抽出の有機溶媒及び ガラス表面などの近傍にある水，（e）超臨界状態等の高温 の水は, 水素結合による大集団化 $\left(n_{\mathrm{w}}>\sim 10^{7}\right)$ を起こす ことが困難ないし不可能であり, 究極的には, 「二水素エ ーテル」([R][H]-O-[H][R] $)^{58)}$ としての本来の性質に「還 元」されてしまうと考えられる.

\section{9 おわりに}

溶液中において化学反応性がほとんどないとされてきた アルカリ金属イオン等には, 実は化学反応に直接関与する ほど強い「錯形成力」が潜在しており，それが顕在化する 場合があるという考えの下に研究を進めた。このようにし て，これまでは「異常現象」として取り扱われてきた共存 塩による溶液内平衡及び反応速度の変動が, 統一的に解釈 できるようになったといえる。しかし，溶媒和力にそしい 溶媒中であれば，そのような相互作用の観測も可能かもし れないが, 水溶液中では, 水の持つ強い水素結合供与性及 び塩基性により, 溶存する大抵の陰イオン及び陽イオンは 反応部位をブロックされてしまっているので，相互作用の 観測は不可能に近いものである. しかし, 化学平衡に基づ く化学種の存在濃度変化そのものを観測する代わりに, 極 微弱な変位を常時蓄積していくこと, すなわち反応速度の 変化に変換すること等により，アルカリ金属イオン等と各 種の陰イオンとの化学的相互作用を「観測可能な実在科学」 として提示できるようになってきた。

分析化学や無機分野では，水溶液反応を扱うことが大半 であり, 非水溶媒中の反応様式には無関心ないし無関係で あってきたかもしれないが，これからは非水溶液反応を利 用する機会が増えてくることは間違いない.ここで, 誤解 が生じる危険を顧みず，あえて記述すると，「水溶液反応 における遷移金属イオン（例えば $\mathrm{Cd}^{2+} ）$ の役割を, 非水 溶媒中ではアルカリ土類金属イオン $\left(\mathrm{Ca}^{2+}\right)$ が同等に果 たすことができる」ということである．水溶液中の $\mathrm{H}^{+}$と 非水溶媒（疎プロトン性溶媒）中の $\mathrm{Li}^{+}$等のアルカリ金属 イオンについても同様の関係になっているようである.

このように，アルカリ金属イオン等が化学結合に直接関 
与するという本概念が，仮想的のもから現実のものになっ たとはいえ，アルカリ金属イオン等に対する一般認識又は 「共通認識」からすると, とうてい容認できない部分が残 るかもしれない，本稿では，これまでほとんど取り上げら れてこなかった「溶液中のアルカリ金属イオン等の化学結 合力」に基づいて研究を展開し, 相互に矛盾のない結論を 導き出すことができるようになっていったことを示した。

\section{文献}

1) 玉虫伶太：“活量とは何か”, p. 60 (1983), (共立出 版).

2) J. F. Coetztee, I. M. Kolthoff: J. Am. Chem. Soc., 79, 6110 (1957).

3) M. Kinugasa, K. Kishi, S. Ikeda: J. Phys. Chem., 77, 1914 (1973).

4) C. K. Mann: "Electroanalytical Chemistry", Vol. 3, Edited by A. J. Bard, p. 69 (1969), (Marcel Dekker, New York).

5) 荒田洋治: “水の書”, p. 48 (1998), (共立出版).

6) 大瀧仁志, 岡田 勲訳: “ドナーとアクセプター”, 第 2 章 (1983), (学会出版センター); V. Gutmann: “The Donor-Acceptor Approach to Molecular Interactions", (1978), (Plenum, New York).

7) 細谷治夫, 湯田坂雅子訳: “基礎物理学 (上)”, p. 123 (1985), (東京化学同人); W. J. Moore: “Basic Physical Chemistry”, (1983), (Prentice-Hall, Englewood Cliffs).

8) 荒木 峻, 益子洋一郎, 山本 修訳: “有機化合物 のスペクトルによる同定法, 第 5 版”, p. 172 (1992), (東京化学同人); R. M. Silverstein, G. C. Bassler, T. C. Morill: "Spectrometric Identification of Organic Compounds", 5th Ed., Chap. 4 (1991), (John Wiley).

9) K. Mizuno, S. Imafuji, T. Ochi, T. Ohta, S. Maeda: J. Phys. Chem. B, 104, 11001 (2000).

10) I. M. Kolthoff, M. K. Chantooni, Jr.: J. Am. Chem. Soc., 85, 426 (1963).

11) M. Hojo, Z. Chen: Anal. Sci., 15, 303 (1999).

12) M. Hojo, H. Hasegawa, Z. Chen: Bull. Chem. Soc. Jpn., 69, 2215 (1996).

13) R. M. Izatt, K. Pawlak, J. S. Bradshaw: Chem. Rev., 91, $1721(1991)$

14) M. Hojo, M. Hagiwara, H. Nagai, Y. Imai : $J$. Electroanal. Chem., 234, 251 (1987).

15) M. Hojo, H. Hasegawa, T. Ohno, S. Arisawa, K. Chayama: Anal. Sci., 11, 419 (1995).

16) M. Hojo, I. Hisatsune, H. Tsurui, S. Minami: Anal. Sci., 16, 1277 (2000).

17) M. Hojo, Y. Imai: J. Electroanal. Chem., 209, 297 (1986).

18) M. Hojo, Y. Imai: Bull. Chem. Soc. Jpn., 56, 1963 (1983).

19) M. Hojo, T. Takiguchi, M. Hagiwara, H. Nagai, Y. Imai : J. Phys. Chem., 93, 955 (1989).

20) M. Hojo, H. Hasegawa, Y. Miyauchi, H. Moriyama, H. Yoneda, S. Arisawa: Electrochim. Acta, 39, 629 (1994).

21) R. W. Murray, L. K. Hiller, Jr.: Anal. Chem., 39, 1221 (1967).

22) E. Itabashi : J. Electroanal. Chem., Interfacial Electrochem., 36, 179 (1972).

23) M. Hojo, A. Tanio, Y. Miyauchi, Y. Imai : Chem. Lett.,
1991, 1827.

24) M. Hojo, Y. Miyauchi, N. Ide, A. Tanio, Y. Imai : J. Electroanal. Chem., 340, 197 (1992).

25) F. Klanberg, J. P. Hunt, H. W. Dodgen: Inorg. Chem., 2, 139 (1963).

26) J. E. Hickey, M. S. Spritzer, P. J. Elving: Anal. Chim. Acta, 35, 277 (1966).

27) K. Tsuji, P. J. Elving: Anal. Chem., 41, 1571 (1969).

28) M. Hojo, Y. Akita, K. Nishikawa, Y. Imai : Bull. Chem. Soc.Jpn., 60, 509 (1987).

29) R. M. Fuoss, C. A. Kraus: J. Am. Chem. Soc., 55, 2389 (1933).

30) B. Gestblom, I. Svorstol, J. Songstad: J. Phys. Chem., 90, 4684 (1986).

31) S. Petrucci, E. M. Eyring: J. Phys. Chem., 95, 1731 (1991).

32) Z. Chen, M. Hojo: J. Phys. Chem. B, 101, 10896 (1997).

33) R. M. Fuoss, F. Accascina: "Electrolytic Conductance", p. 256 (1959), (Interscience).

34) M. Hojo, T. Ueda, Z. Chen, M. Nishimura: J. Electroanal. Chem., 468, 110 (1999).

35) Y. Miyauchi, M. Hojo, H. Moriyama, Y. Imai : J. Chem. Soc., Faraday Trans., 88, 3175 (1992).

36) T. Shedlovsky: J. Franklin Inst., 225, 739 (1938).

37) Y. Wu, H. L. Friedman: J. Phys. Chem., 70, 501 (1966).

38) M. L. Jansen, H. L. Yeager: J. Phys. Chem., 78, 1380 (1974).

39) J. Barthel, H.-J. Gores, L. Kraml: J. Phys. Chem., 100, 3671 (1996).

40) M. Hojo, T. Ueda, M. Nishimura, H. Hamada, M. Matsui, S. Umetani: J. Phys. Chem. B, 103, 8965 (1999).

41) G. Ruderman, E. R. Caffarena, I. G. Mogilner, E. J. Tolosa: J. Solution Chem., 27, 935 (1998).

42) K. Suzuki, Y. Taniguchi, T. Watanabe: J. Phys. Chem., 77, 1918 (1973).

43) A. Katchalsky, H. Eisenberg, S. Lifson: J. Am. Chem. Soc., 73, 5889 (1951).

44) D. A. MacInnes, T. Shedlovsky: J. Am. Chem. Soc., 54, 1429 (1932).

45) 北條正司, 長谷川 浩, 日浦徳孝：平成 6 年度日本 化学会中国四国地区化学教育研究協議会高知大会講 演要旨集, p. 30 (1994).

46) M. Hojo, H. Hasegawa, H. Tsurui, K. Kawamura, S. Minami, A. Mizobe: Bull. Chem. Soc.Jpn., 71, 1619 (1998).

47) M. Hojo, T. Ueda, K. Kawamura, M. Yamasaki : Bull. Chem. Soc. Jpn., 73, 347 (2000).

48) M. Hojo, T. Ueda, M. Yamasaki, A. Inoue, S. Tokita, M. Yanagita: Bull. Chem. Soc.Jpn., 75, 1569 (2002).

49) M. Hojo, H. Hasegawa, H. Yoneda: Bull. Chem. Soc. Jpn., 69, 971 (1996).

50) M. Hojo, T. Ueda, A. Inoue: Bull. Chem. Soc. Jpn., 75, 2629 (2002).

51) M. Hojo, H. Hasegawa, H. Yoneda: J. Chem. Soc., Perkin Trans. 2, 1994, 1855.

52) M. Hojo, H. Hasegawa, A. Mizobe, Y. Ohkawa, Y. Miimi : J. Phys. Chem., 99, 16609 (1995).

53) M. Baaz, V. Gutmann, O. Kune: Monatsh. Chem., 93, 1142 (1962).

54) M. Hojo, T. Ueda, M. Yamasaki : J. Org. Chem., 64, 4939 (1999). 
55) M. Hojo, T. Ueda, M. Yamasaki, A. Inoue: Anal. Sci., 16, 649 (2000).

56) L. C. Manege, T. Ueda, M. Hojo: Bull. Chem. Soc. Jpn., 71, 589 (1998).

57) L. C. Manege, T. Ueda, M. Hojo, M. Fijio: J. Chem. Soc., Perkin Trans. 2, 1998, 1961.

58) M. Hojo, T. Ueda, S. Inoue, Y. Kawahara: J. Chem. Soc., Perkin Trans. 2, 2000, 1735.

59) H. S. Frank, W.-Y. Wen: Discuss. Faraday Soc., 24, 133 (1957).

60) Y. Yoshimura, H. Kanno: J. Raman Spectrosc., 27, 671 (1996).

61) J. R. Scherer, M. K. Go, S. Kint: J. Phys. Chem., 78, 1304 (1974).

62) G. Brink, M. Falk: Can. J. Chem., 48, 3019 (1970).

63) R. E. Verrall: "Infrared Spectroscopy of Aqueous
Electrolyte Solutions", in "Water, A Comprehensive Treatise, Vol. 3”, Edited. by F. Franks, Chap. 5 (1973), (Plenum).

64) A. Nose, M. Hojo, T. Ueda: J. Phys. Chem. B, 108, 798 (2004).

65) J. E. Gordon: "The Organic Chemistry of Electrolytes Solutions", p. 167 (1975), (John Wiley).

66) H. Nagayama, M. Hojo, T. Ueda, Y. Nishimori, M. Okamura, C. Daike: Anal. Sci., 17, 1413 (2001).

67) J. Bjerrum, A. S. Halonin, L. H. Skibsted: Acta Chem. Scand. A, 29, 326 (1975).

68) P. Postorino, R. H. Tromp, M.-A. Ricci, A. K. Soper, G. W. Neilson: Nature, 366, 668 (1993).

69) E. H. Oelkers, H. C. Helgeson: Science, 261, 888 (1993).

\section{要旨}

水溶液中における比較的低濃度のアルカリ金属塩及びアルカリ土類金属塩は，「無関係塩」又は支持電解 質として取り扱うことができ，その溶液中のイオン種の平均活量倸数は簡単に評価できる．低誘電率媒体中 $\left(\varepsilon_{\mathrm{r}}<10\right)$ では, $1: 1$ 型電解質から高次のイオン会合が起こることは広く受け入れられているが, 高誘電率 媒体中では高次イオン会合は起こらないものとして取り扱われてきた。しかし，溶質に対する溶媒和力が弱 い非水溶媒中 $\left(20<\varepsilon_{\mathrm{r}}<65\right)$ では，陽イオンと陰イオン間に，クーロン力だけではなく錯形成力などの化 学的相互作用が働き，イオン対に加えて高次のイオン会合体が生成できることを明らかにした。アセトニト リルやベンゾニトリルなど水素結合供与性及び受容性にそしい疎プロトン性溶媒中では，酸（HA）とその 共役塩基イオン $\left(\mathrm{A}^{-}\right)$間の水素結合力によるホモ共役種， $\mathrm{A}^{-}(\mathrm{HA})_{n}$ が生成しやすい。非水溶液中で，ある 化学種に対して, $\mathrm{Li}^{+}$などの金属イオン又は $\mathrm{Cl}^{-}$などの陰イオンが直接反応することを確認し，化学平衡に 及ぼす「塩効果」を単なる “medium effect”としてではなく，化学的相互作用に基づいて統一的に解䣋し た. 水のバルク水としての特性は，水素結合による水分子の大集団化によって初めてもたらされるものであ るとし，大集団化が実現できない条件下では，水の特性は「二水素エーテル」に「還元」され，このような 「水溶液」中では，基本的には，上に述べた非水溶液中と同様の反応が起こり得ると論じた．化学平衡的に は, 観測できないほど微小な反応中間体濃度の増加が, 観測可能な大きな反応速度の変化として測定され, 水の構造性が低下した水溶液中でのイオン間の化学的相互作用が実証された。 